\title{
The $\alpha$ Crystallin Domain of Small Heat Shock Protein b8 (Hspb8) Acts as Survival and Differentiation Factor in Adult Hippocampal Neurogenesis
}

\author{
Gerardo Ramírez-Rodríguez, ${ }^{1}$ Harish Babu, ${ }^{2}$ Friederike Klempin, ${ }^{3}$ Olga Krylyshkina, ${ }^{4}$ Veerle Baekelandt, ${ }^{4}$ \\ Rik Gijsbers, ${ }^{5}$ Zeger Debyser, ${ }^{5}$ Rupert W. Overall, ${ }^{6}$ Zeina Nicola, ${ }^{6}$ Klaus Fabel, ${ }^{6,7}$ and Gerd Kempermann ${ }^{6,7}$ \\ ${ }^{1}$ Laboratory of Neurogenesis, Division of Clinical Investigations, National Institute of Psychiatry Ramón de la Fuente Muñiz, 14370 México, D.F. México, \\ ${ }^{2}$ Department of Neurosurgery, Stanford University, Stanford, California 94305, ${ }^{3}$ Institute for Stem Cell and Regenerative Medicine, University of \\ Washington, Seattle, Washington 98109, ${ }^{4}$ Laboratory for Neurobiology and Gene Therapy, and ${ }^{5}$ Laboratory for Molecular Virology and Gene Therapy, \\ Division of Molecular Medicine, Katholieke Universiteit Leuven, B3000 Leuven, Flanders, Belgium, ${ }^{6}$ Center for Regenerative Therapies Dresden, 01307 \\ Dresden, Germany, and ${ }^{7}$ German Center for Neurodegenerative Diseases Dresden, 01307 Dresden, Germany
}

Adult hippocampal neurogenesis is to a large degree controlled at the level of cell survival, and a number of potential mediators of this effect have been postulated. Here, we investigated the small heat shock protein $\mathrm{Hspb8}$, which, because of its pleiotropic prosurvival effects in other systems, was considered a particularly promising candidate factor. Hspb8 is, for example, found in plaques of Alzheimer disease but exerts neuroprotective effects. We found that expression of Hspb8 increased during differentiation in vitro and was particularly associated with later stages $(48-96 \mathrm{~h})$ of differentiation. Gain-of-function and loss-of-function experiments supported the hypothesis that Hspb8 regulates cell survival of new neurons in vitro. In the dentate gyrus of adult mice in vivo, lentiviral overexpression of Hspb8 doubled the surviving cells and concomitantly promoted differentiation and net neurogenesis without affecting precursor cell proliferation. We also discovered that the truncated form of the crystallin domain of Hspb8 was sufficient to affect cell survival and neuronal differentiation in vitro and in vivo. Precursor cell experiments in vitro revealed that Hspb8 increases the phosphorylation of Akt and suggested that the prosurvival effect can be produced by a cell-autonomous mechanism. Analysis of hippocampal Hspb8 expression in mice of 69 strains of the recombinant inbred set BXD revealed that $H s p b 8$ is a cis-acting gene whose expression was associated with clusters of transcript enriched in genes linked to growth factor signaling and apoptosis. Our results strongly suggest that Hspb8 and its $\alpha$-crystallin domain might act as pleiotropic prosurvival factor in the adult hippocampus.

\section{Introduction}

Adult hippocampal neurogenesis is dominantly regulated at the level of the survival of newborn neurons. In 26 strains of the BXD recombinant inbred panel of mice, $85 \%$ of the variability in adult neurogenesis was explained by cell survival, whereas precursor cell proliferation explained only 19\% (Kempermann et al., 2006). Learning and environmental complexity recruit more new neurons by increasing survival.

Relatively little is known about the molecular mechanisms underlying this survival-promoting effect, although specific sur-

\footnotetext{
Received Dec. 24, 2011; revised Jan. 28, 2013; accepted Feb. 12, 2013

Author contributions: G.R.-R., H.B., and G.K. designed research; G.R.-R., H.B., F.K., O.K., V.B., R.G., Z.D., R.W.O., Z.N., and K.F. performed research; G.R.-R., H.B., F.K., R.W.O., Z.N., and G.K. analyzed data; G.R.-R. and G.K. wrote the paper.

This work was supported by VolkswagenStiftung and by Consejo Nacional de Ciencia y Tecnología (CBSEP-2008-101316). We thank Ruth Zarmstorff, Signe Knespel, Leonardo Ortiz-Lopez, Ariadna GómezSánchez, and Daniela Lasse for technical assistance and Dr. Marco A. Meraz-Ríos (Centro de Investigación y de Estudios Avanzados del Instituto Politécnico Nacional-México) and Dr. Benito Antón-Palma (Instituto Nacional de Psiquiatría Ramón de la Fuente Muñiz) for their support to perform additional experiments.

The authors declare no competing financial interests.

Correspondence should be addressed to Dr. Gerd Kempermann, Center for Regenerative Therapies Dresden, Fetscherstraße 105, 01307 Dresden, Germany. E-mail: gerd.kempermann@crt-dresden.de.

DOI:10.1523/JNEUROSCI.6452-11.2013

Copyright $\odot 2013$ the authors $\quad 0270-6474 / 13 / 335785-12 \$ 15.00 / 0$
}

vival effects have been seen in many experiments (e.g., Pieper et al., 2010; Sahay et al., 2011). Reported mediators include neurotrophic factors, most notably BDNF, hormones, and cytokines (Rossi et al., 2006; Galea, 2008; Mueller et al., 2008; Peng et al., 2008; Pinnock and Herbert, 2008; Mastrangelo et al., 2009; Pawluski et al., 2009; Zhang et al., 2009; Koo et al., 2010; Leuner et al., 2011). We have reported that melatonin has an almost exclusive effect on survival and maturation of newborn neurons in the adult dentate gyrus (Ramírez-Rodríguez et al., 2009, 2011). At the intracellular level, the role of antiapoptotic factors, such as $\mathrm{Bcl} 2$, have been described and functional studies suggest that the activity-dependent promotion of survival is linked to the active elimination of new cells (Perera et al., 2007).

Small heat shock proteins are interesting candidate molecules to orchestrate complex functions because of their pleiotropic effects (Wang et al., 2004; Yew et al., 2005; Depre et al., 2006; Quraishe et al., 2008; Gurusamy et al., 2009; Sui et al., 2009; Karch and Borchelt, 2010; Gonzalez-Malerva et al., 2011; Kirbach and Golenhofen, 2011). They are well suited as evolutionarily conserved mediators of "activity," considering their name-giving ability to upregulate their expression in response to stressors. Hspb8 has mainly been studied in the heart, where it exerts a plethora of prosurvival functions, including the stimulation of 
glycogen synthesis (Wang et al., 2004), potentiation of BMP signaling (Sui et al., 2009), and buffering oxidative stress, among other mechanisms by modifying SOD (Karch and Borchelt, 2010). Overexpression of Hspb8 caused cardiac hypertrophy by promoting cell proliferation and survival through an Aktmediated pathway (Sui et al., 2009).

$H s p b 8$ is expressed in the brain; and according to the Allen Brain Atlas, its expression is concentrated in (but not limited to) the neurogenic niche of the hippocampus (www.brain-map.org; Hspb8-Sagittal-b04-0153), where its expression is upregulated as an early response to hypoxia (David et al., 2006). In addition, Hspb8 is expressed in cultured hippocampal neurons (Kirbach and Golenhofen, 2011).

Hspb8 is linked to neuronal survival by its interaction with Bag3 to induce macroautophagic removal of misfolded proteins (Yew et al., 2005; Gurusamy et al., 2009). This chaperone activity has been shown for amyotrophic lateral sclerosis (Crippa et al., 2010) and proposed for Alzheimer disease (Wilhelmus et al., 2006). Mutations of $H s p b 8$ are involved in the hereditary peripheral neuropathy of Charcot-Marie-Tooth neuropathy type 2 (Tang et al., 2005; Irobi et al., 2010). Based on our preliminary observation and this literature, we set out to investigate $\mathrm{Hspb} 8$ as potential pleiotropic survival factor in adult hippocampal neurogenesis.

Hspb8 is also known as H11 kinase, Hsp22, Hsp20-like, or $\alpha \mathrm{C}$ Crystallin (Cryac). It is not to be confused with Hsp27/Hspb5 $(\alpha \mathrm{B}$ Crystallin) on which a larger literature exists (e.g., Hagemann et al., 2009).

\section{Materials and Methods}

Animals. C57BL/6 mice were obtained from Charles River. They were held in standard laboratory cages with a light cycle of $12 \mathrm{~h}$ lights on and $12 \mathrm{~h}$ lights off. The animals had access to food and water ad libitum at the animal facility of the Max Delbrück Center for Molecular Medicine Berlin-Buch, Germany. A total of 80 female mice, 8 weeks old at the beginning of the experiment, were used. All animal work was performed according to the rules of directive of the European Union and was approved by the responsible authority, Landesamt für Gesundheit und Technische Sicherheit Berlin.

Isolation of adult hippocampal precursor cells (AHPCs). AHPCs were isolated from the hippocampus of adult female mice as previously reported (Babu et al., 2011). Briefly, animals were killed by cervical dislocation. Brains were removed from the skull and placed in cold artificial CSF (aCSF) containing $124 \mathrm{~mm} \mathrm{NaCl}, 2.5 \mathrm{~mm} \mathrm{KCl}, 1 \mathrm{~mm} \mathrm{CaCl}_{2}, 1 \mathrm{~mm}$ $\mathrm{MgCl}_{2}, 25 \mathrm{~mm} \mathrm{NaHCO}, 10 \mathrm{~mm}$ D-glucose. Hippocampal coronal slices (300 $\mu \mathrm{m})$ were obtained using a vibratome to dissect out the dentate gyrus. Dentate gyri were dissociated by enzymatic digestion and cell suspension separated by centrifugation using a Percoll gradient.

Precursor cells were plated on laminin-precoated coverslips or $96 \mathrm{mul}$ tiwell plates and cultured with $20 \mathrm{ng} / \mathrm{ml}$ of human EGF and $20 \mathrm{ng} / \mathrm{ml}$ of human FGF-2 (both from PeproTech) in Neurobasal medium supplemented with B27 (Invitrogen), for $24 \mathrm{~h}$.

Western blot (immunoblotting). Precursor cells were lysed as reported previously (Babu et al., 2009; Ramírez-Rodríguez et al., 2009). Total lysate from AHPCs was obtained with RIPA buffer $(150 \mathrm{~mm} \mathrm{NaCl}, 10 \%$ glycerol, $0.5 \mathrm{~mm}$ EDTA, 0.5\% Triton X-100, $1 \mathrm{~mm}$ PMSF, $25 \mu \mathrm{g} / \mathrm{ml}$ leupeptin, $25 \mu \mathrm{g} / \mathrm{ml}$ aprotinin, and $1 \mathrm{~mm}$ sodium ortho-vanadate in 50 $\mathrm{mm}$ Tris- $\mathrm{HCl}, \mathrm{pH}$ 7.6) and homogenized with an ultrasonic homogenizer for $30 \mathrm{~s}$. Cellular debris was removed by centrifugation at $14,000 \times g$. Total protein content was quantified using Bradford reagent (Bio-Rad). Protein separation was performed by the Laemmli method (Cleveland et al., 1977) and transferred to PVDF or nitrocellulose paper. Membranes were blocked with 5\% skim milk in $0.05 \%$ Tween 20 -TBS and incubated with the goat anti-Hspb8 1:500 (Abcam); rabbit-anti-Hspb8 1:3000 (a kind gift from Dr. Roelfs, Radboud University Nijmegen, Nijmegen, The Netherlands); goat- or mouse-anti-GFP (1:500, Abcam); rabbit-antiphospho AKT or rabbit anti-AKT (1:1000, Cell Signaling) or with the mouse anti-GAPDH antibody 1:5000 (Millipore Bioscience Research Reagents, Hampshire, England). Blots were washed 3 times with Tween 20-TBS and incubated for $1 \mathrm{~h}$ in a 1:3000 dilution of phosphataseconjugated donkey anti-mouse; donkey anti-goat; donkey anti-rabbit antibodies. Proteins were visualized with the enhanced chemiluminescence detection system. Autoradiograms were scanned with a GS-800 densitometer and PDQuest Advanced Software (Bio-Rad).

Standard RT-PCR and qRT-PCR. The expression of Hspbs in AHPC was analyzed by RT-PCR. RNA was isolated using RNeasy (QIAGEN), and cDNA was generated using the Superscript system (Invitrogen). Products were separated on $1 \%$ agarose gels. Primer sequences for $H s p b 8$ (forward, TGAATTCCGACCAACATCATGGCTGAC; reverse, GAAG TCGACCAAGGCTGACGTCTTAG) were from BioTez.

For analyzing expression changes of $H s p b 8$ during neural precursor differentiation in culture, RNA was extracted as was mentioned above at $0,12,24,48$, and $96 \mathrm{~h}$, respectively. RNA samples were adjusted to 1 $\mu \mathrm{g} / \mu \mathrm{l}$ and stored at $-80^{\circ} \mathrm{C}$. Three independent reverse transcriptase (RT) reactions were performed for each RNA sample using oligo(dT) primers and Superscript II RNase $\mathrm{H}$ reverse transcriptase, followed by incubations with RNase $\mathrm{H}$ (Invitrogen) for $20 \mathrm{~min}$ at $37^{\circ} \mathrm{C}$. Primer sequences were as follows: forward, CATCTCAAGCCACATCACCTTG; reverse, GGCCAGGCAGAGGAGAGC. Quantitative PCR was performed in a reaction mix containing SYBR Green (Quantitect SYBR Green PCR kit, QIAGEN). The products were detected with an Opticon DNA Engine (MJ Research). A melting curve analysis verified the specificity of the reaction. The PCR protocol was as follows: $95^{\circ} \mathrm{C}$ for $15 \mathrm{~min}$; $94^{\circ} \mathrm{C}$ for $30 \mathrm{~s} ; 58^{\circ} \mathrm{C}$ for seconds; $72^{\circ} \mathrm{C}$ for seconds; 40 cycles from steps $2-4$ followed by a melting curve from $55^{\circ} \mathrm{C}-90^{\circ} \mathrm{C}$. The relative amount of the tested transcript was normalized to the level of Gapdh using specific primers set all obtained from BioTez.

Plasmid constructs. The full-length of $H s p b 8$ was amplified from cDNA of neural precursor cells by PCR with primers that flank the open reading frame (forward,TGAATTCCGACCAACATCATGGCTGAC;reverse, GA AGTCGACCAAGGCTGACGTCTTAG) and ligated into the pIRES2EGFP vector at the EcoRI/SalI sites. The pIRES2-EGFP vector enables Hspb8 to be expressed together with the EGFP from a single bicistronic mRNA. For cloning the Hspb8 truncated in the 120-145 residues corresponding to the $\alpha$ crystallin domain ( $\Delta$ Hspb8), we used two primer sets (forward,TGAATTCCGACCAACATCATGGCTGAC;reverse,CTCTGC AGTATCCATCCTTGGTCTTTAC; and reverse, TTCCTGCAGAAGTG GATCCAGCCA; forward, GAAGTCGACCAAGGCTGACGTCTTAG), both fragments were digested using the enzymes EcoRI/PstI and PstI/ SalI, respectively, and ligated into the pIRES2-EGFP vector at the EcoRI/ SalI. The sequences of the full-length and the truncated Hspb8 $(\Delta \mathrm{Hspb} 8)$ were verified by sequencing.

Precursor cell electroporation (overexpression and knock-down). Electroporation of precursor cells with the p-Hspb8-IRES2-eGFP and p- $\Delta$ Hspb8-IRES2-eGFP was performed as described previously (Lie et al., 2005; Jessberger et al., 2008). Briefly, precursors were detached, and $1 \times 10^{6}$ cells were transfected with $10 \mu \mathrm{g}$ of the respective DNA using the Nucleofector II electroporation device according to the manufacturer's instructions (Amaxa). After transfection, cells were plated at $2.5 \times 10^{4}$ or $1 \times 10^{5}$ densities, depending on the parameter that would be evaluated. After $48 \mathrm{~h}$, cells cultured in proliferation conditions were induced to differentiate during 4 additional days. Proportions of neurons that expressed GFP were identified by MAP2 expression. Protein expression was verified $36 \mathrm{~h}$ after transfection.

For knocking down expression of $H s p b 8$, AHPCs were electroporated with sense and antisense siRNA oligonucleotides. The control siRNA was from Ambion, and Hspb8-siRNA was from MWG-Biotech. The Hspb8siRNA sequence was as follows: sense, CAACGAGCUUCCUCAAGAC; antisense, GUCUUGAGGAAGCUCGUUG. The resuspended duplexes were aliquoted and stored at $-20^{\circ} \mathrm{C}$. The electroporation of precursor cells with siRNA was performed according to the protocol provided by Amaxa. Briefly, before electroporation, cells were detached and $1 \times 10^{6}$ cells were mixed with $160 \mathrm{~nm}$ of siRNA duplexes and $2 \mu \mathrm{g}$ of control GFP plasmid DNA (pmaxGFP, Amaxa). Then, AHPCs were plated and cultured under proliferation conditions during $48 \mathrm{~h}$. Thus, cells were induced to differentiate during 4 additional days. The proportion of neurons that coexpress GFP 
and $\beta$ III-tubulin were identified in randomized fields. Silencing of $H s p b 8$ in precursor cells was confirmed by immunobloting.

Approximately 200-300 cells were quantified. The analyzer was blinded for the experimental conditions. Every experiment was performed at least three times as duplicates. Additionally, conditioned media (CM) from precursor cells expressing the pIRES2-EGFP, p-Hspb8-IRES2-eGFP, or from cells transfected with the control siRNA or Hspb8-siRNA was collected to determine a possible cell-autonomous or non-cell-autonomous effect of Hspb8 on precursor cell proliferation or survival determined by WST-1 and BrdU incorporation using ELISA-based assay.

Immunocytochemistry. Cultures were fixed with $4 \%$ paraformaldehyde in $0.1 \mathrm{~m}$ PBS, pH 7.4, for $20 \mathrm{~min}$. After PBS washing, cells were permeabilized with $0.5 \%$ Triton X-100 in PBS for 30 min. Nonspecific sites were blocked with 5\% donkey serum (Millipore Bioscience Research Reagents) containing $0.5 \%$ Triton $\mathrm{X}-100$ (blocking buffer), freealdehyde groups were reduced with $1 \mathrm{~m}$ glycine for $20 \mathrm{~min}$. Primary antibodies were diluted in blocking buffer and monolayer incubated overnight at $4^{\circ} \mathrm{C}$. After washes with PBS, incubation with secondary antibodies was allowed for $2 \mathrm{~h}$ at room temperature. The primary antibodies were as follows: goat anti-Hspb8 1:500 and monoclonal mouse anti-Hspb8 1:500 (Abcam); monoclonal mouse anti-Nestin 1:400 (BD Biosciences); monoclonal mouse anti- $\beta$ III-tubulin 1:1000 (Promega); rabbit anti- $\beta$ III-tubulin (TuJ1) 1:1000 (Covance); guinea-pig anti-GFAP 1:1000 (Advanced Immunochemistry); rat anti-BrdU 1:500 (Biozol); and mouse anti-eGFP 1:500 (Abcam). Secondary antibodies raised in donkey (Jackson ImmunoResearch-Dianova) were used at 1:250. Colabeled cells were quantified in randomized fields using a Leica TCS SP2 confocal microscope (Leica). All analyses were done in sequential scanning mode to avoid false positive colabeling.

Lentiviral vectors. The control vector was pCH_CMV_eGFPWS_Isa and to generate the Hspb8 and $\Delta \mathrm{Hspb} 8$ vectors, we cloned their cDNA upstream of the IRES and EGFP and inserted the bicistronic cassette in place of the GFP sequence in the pCH_CMV_eGFPWS_Isa vector. The empty vector was generated inserting the bicistronic cassette (IRES2EGFP) in place of the GFP sequence. Concentrated lentiviral vectors (LV) stocks, pseudotyped by the vesicular stomatitis viral envelope, were produced as described previously (Geraerts et al., 2006). Expression titers, determined in $293 \mathrm{~T}$ cells by FACS analysis, were $1.65 \times 10^{8}$ to $3 \times$ $10^{8}$ transducing units/ml with a p24 concentration of $1.38 \times 10^{6}$ to $2.95 \times 10^{6} \mathrm{pg} / \mathrm{ml}$.

Surgical procedure and immunohistochemistry. Mice were stereotactically injected with $2 \mu \mathrm{l}$ of the LV containing Hspb8 or $\Delta \mathrm{Hspb} 8$ and GFP into the right hemisphere of the dentate gyrus. Coordinates from bregma in $\mathrm{mm}$ are as follows: anteroposterior -2.3 , mediolateral -1.7 , dorsoventral -1.7 . For control group, $2 \mu \mathrm{l}$ of control GFP expressing LV was injected. The group size was $n=5$ or 6 mice.

To study the effects of Hspb8 and $\Delta \mathrm{Hspb} 8$ expression on cell proliferation in the hippocampus, adult mice were injected three times with BrdU (50 mg/kg body weight i.p.; Sigma-Aldrich) $6 \mathrm{~h}$ apart, starting the first injection at 3 weeks after lentiviral injection. Mice were killed $2 \mathrm{~h}$ after the last BrdU injection. For survival/differentiation studies, the same BrdU injection protocol was applied and animals were killed at 3 weeks after the last BrdU administration.

Mice were deeply anesthetized with ketamine and perfused transcardially with $0.9 \%$ sodium chloride followed by $4 \%$ paraformaldehyde in $0.1 \mathrm{M}$ phosphate buffer, $\mathrm{pH}$ 7.4. Brains were removed from the skulls and postfixed overnight. After fixation, brains were transferred into $30 \%$ sucrose. Brains were cut into $40 \mu \mathrm{m}$ coronal sections on a sliding microtome (Leica) and cryoprotected. Sections were stained free-floating with antibodies diluted in Tris-buffered saline containing $3 \%$ donkey serum and 0.1 Triton X-100. For BrdU, DNA was denatured in $2 \mathrm{~N} \mathrm{HCl}$ for $30 \mathrm{~min}$ at $37^{\circ} \mathrm{C}$. To study the distribution of Hspb8 and its coexpression in the course of adult hippocampal neurogenesis, we used a Nestin-GFP mouse.

Primary antibodies were applied in the following dilutions: rabbit anti-Hspb8 (1:100; ProteinTech); goat anti-double-cortin (1:200; Santa Cruz Biotechnology); monoclonal anti-calretinin (1:500; Swant); monoclonal mouse anti-NeuN (1:100; Millipore Bioscience Research Reagents); rabbit anti-S100 $\beta$ (1:250; Swant); goat anti-GFP (1:500, Abcam); and rat anti-BrdU (1:500, Biozol). Fluorophore-coupled sec- ondary antibodies were as follows: anti-rat TRITC, anti-mouse Cy5, antirabbit Cy5, and anti-goat FITC. All secondary antibodies were raised in donkey and diluted 1:100 or 1:250 (Jackson ImmunoResearch-Dianova). Sections were coverslipped in polyvinyl alcohol with diazabicyclo-octane as antifading agent.

Phenotypic analysis in vivo. Areas transduced by LV were identified by expression of GFP. The proliferation and survival rates were expressed as mean of BrdU/GFP ${ }^{+}$cells per animal. For phenotypic analysis of lentiviral-labeled cells, one-in-12 series of sections were triple-stained with immunofluorescence as described above. Fifty BrdU-labeled cells within the subgranular and granule cell layer were analyzed for coexpression of the different markers.

The colabeling of BrdU/GFP/NeuN and BrdU/GFP/S100 $\beta$, respectively, identified new neurons and new astrocytes in the hippocampus. Analysis was done by $3 \mathrm{D}$ confocal microscopy in sequential scanning mode. Newly generated neurons and astrocytes in infected areas are shown as fraction related to the control group (Kempermann et al., 2004).

Bioinformatic analysis. Quantitative trait locus (QTL) mapping was done using data and online tools available from the GeneNetwork repository (http://www.genenetwork.org). The analysis used a hippocampal mRNA expression dataset measured using Affymetrix M430 version 2 microarrays and normalized with the PDNN method (Overall et al., 2009). This dataset is accessible as "Hippocampus Consortium M430v2 (Jun06) PDNN" from the GeneNetwork website. Gene enrichment analysis was done with the DAVID online database (http://david.abcc.ncifcrf.gov) (Huang da et al., 2009a, 2009b) using all genes present on the microarray as background. The interaction network was generated using the STRING tool (http://string.embl.de) (Snel et al., 2000; Szklarczyk et al., 2011).

Statistical analysis. Analysis was performed using SigmaStat 3.1 and Statview 5.0.1 software. Results are presented as mean \pm SEM. Statistical analysis from the in vitro and in vivo data was performed using one-way ANOVA, followed by appropriated post hoc test. Differences were considered statistically significant at $p=0.05$.

\section{Results}

\section{Hspb8 is expressed during adult neural precursor cell differentiation}

Immunohistochemical investigations with antibodies against $\mathrm{Hspb} 8$ revealed that the protein is expressed in the dentate gyrus, the $\mathrm{CA}$ fields, and the hilus of the hippocampus of adult mice (Fig. 1A,B), confirming the mRNA distribution seen in the Allen Brain Atlas. The expression of Hspb8 in the dentate gyrus was corroborated by PCR and Western blot after microdissection (Fig. $2 B, C$ ). To analyze the expression of Hspb8 in the hippocampus, we performed immunostainings in tissue sections from Nestin-GFP reporter mice (Fig. 1). We detected that Hspb8 is widely expressed in the hippocampus, including in the wall of blood vessels (Fig. 1). To investigate which cells would express Hspb8 in the course of adult hippocampal neurogenesis, we colabeled Hspb8 with different markers of neurogenesis (Fig. 1). We detect Hspb8-staining in some Nestin-positive type 1 and type 2 a cells (Fig. 1C). However, we found more colabeling with Hspb8 in type 2b cells (Nestin/DCX-positive; Fig. 1C). Also, postmitotic new neurons expressing calretinin (Fig. 1D) colabeled with Hspb8. Strongest expression of Hpb8 was seen in the population of mature granule cell neurons that also coexpressed NeuN (Fig. 1E). These results indicated that Hspb8 is expressed during various developmental stages in the course of adult hippocampal neurogenesis.

We next analyzed the expression of Hspb8 in neural precursor cells isolated from the dentate gyrus of adult mice. Neural precursor cells cultured under proliferation conditions are polygonal and bipolar with plump and short processes (Fig. $2 A$ ). Hspb8 showed a punctuate pattern in the cytoplasm of precursor cells (Fig. 2A3). Again the presence of Hspb8 was confirmed by PCR and Western blot (Fig. $2 B, C$ ). Western blot autoradiograms showed low levels of Hspb8 in proliferating precursor cells (Fig. 2D). 
We next investigated the changes of mRNA expression and protein during the process of differentiation in vitro. In the course of differentiation, the cells started to extend long thin neurites after 12-24 h (Fig. $3 A 1)$ and reached their maximal neurite length at $96 \mathrm{~h}$ after the induction of differentiation. Most of these neurites made connections with adjacent cells creating a network (Fig. 3A2). Hspb8 mRNA was significantly increased at 48 and $96 \mathrm{~h}$ after induction of cell differentiation compared with earlier time points ( $p<0.0002$; Fig. $3 B)$. In addition to the changes in the transcript, the levels of Hspb8 protein increased. Hspb8 protein levels were low under proliferation conditions, similarly to those shown in Figure $2 C$; and also at $12 \mathrm{~h}$ after the initiation of differentiation. However, Hspb8 slightly increased after $24 \mathrm{~h}$ of differentiation reaching a maximum at $96 \mathrm{~h}$ (Fig. 3C). This time course of expression suggested a primary relevance of Hspb8 during relatively more advanced stages of differentiation, presumably including but not limited to survival per se.

\section{Hspb8 is required for precursor cell} differentiation and survival in vitro To further test for the functional involvement of Hspb8 in differentiation and survival, adult hippocampal precursor cells in vitro were transfected with Hspb8, and the effect on neuronal differentiation was evaluated at $4 \mathrm{~d}$ after the induction of differentiation (Fig. 4A). Overexpression of Hspb8 was confirmed by immunoblotting of GFP as cotransfected reporter and Hspb8 (Fig. 4B1). To analyze the effects of Hspb8 on cell differentiation, we performed immunocytochemistry against GFP and MAP2ab on the cells in vitro (Fig. 4B2). MAP2ab was used as marker for relatively mature neurons in vitro (Babu et al., 2009). Overexpression of Hspb8 significantly increased neuronal differentiation by $\sim 66 \%$ compared with cells nucleofected with the control plasmid ( $p=0.001$; Fig. $4 C$ ). The effect of Hspb8 on neuronal differentiation was accompanied by an increase of $22 \%$ in cell survival after $4 \mathrm{~d}$ of differentiation $(p=0.001$; Fig. 4D).

We next silenced $H s p b 8$ with specific siRNA sequences by nucleofection and verified protein expression after the induction of differentiation (Fig. $5 A-C$ ). Western blot analysis confirmed a decrease in $\mathrm{Hspb} 8$ protein expression after siRNA transfection (Fig. $5 \mathrm{C}$ ). Silencing $\mathrm{Hspb} 8$ caused a significant decrease in neuronal differentiation of cells that coexpressed GFP and the early pan-neuronal marker $\beta$ III-tubulin by $\sim 60 \%$ $(p=0.011$, Fig. $5 D)$, and also in cell survival $(p=0.004$, Fig. $5 E)$.

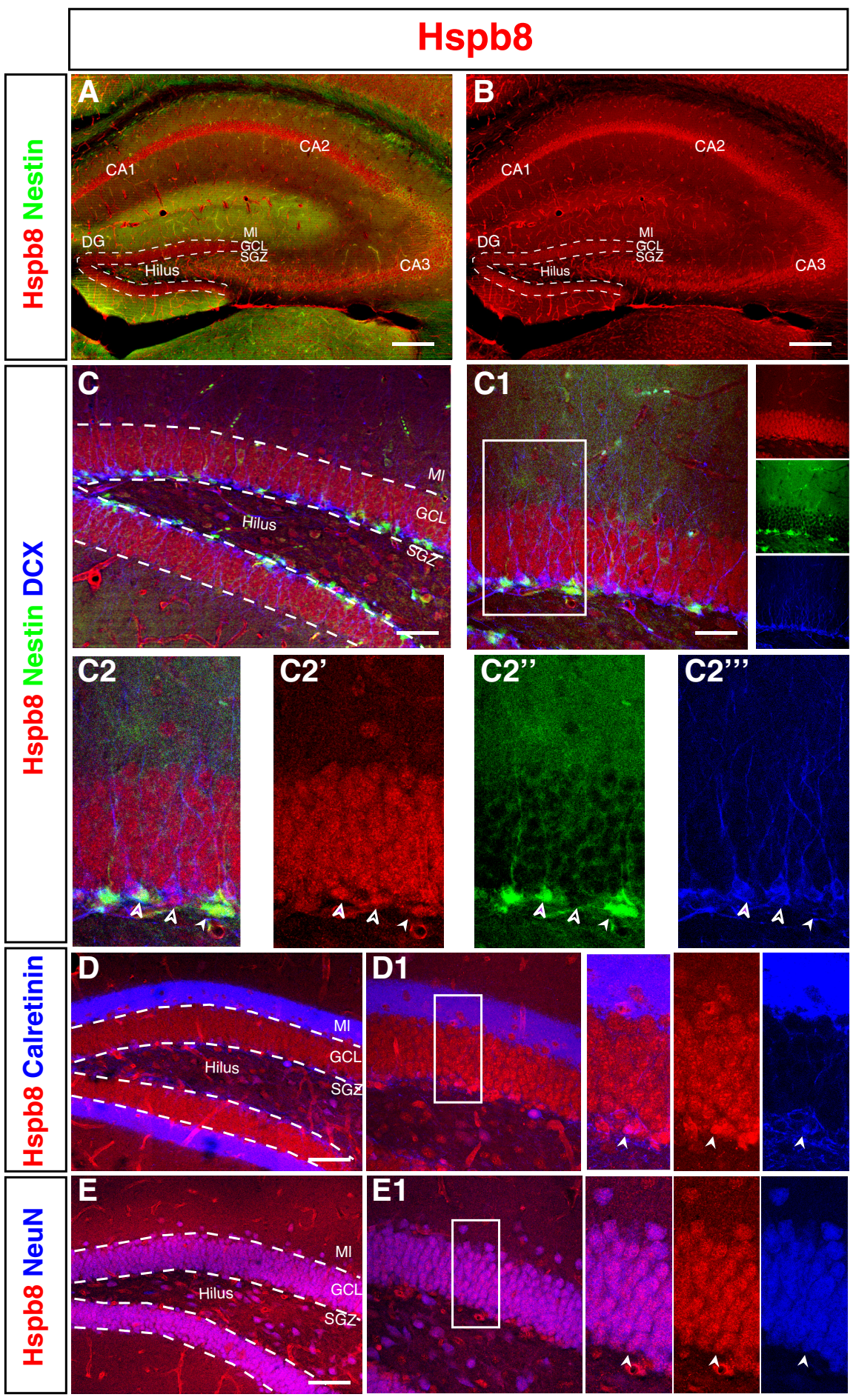

Figure 1. Hspb8 is expressed in the dentate gyrus (DG) of adult mice. Immunofluorescent labeling reveals the expression of $\mathrm{Hspb8}$ in the hippocampus of adult mice. $A, B$, The protein (red) appears to be more concentrated in the DG, $C A 3, C A 2, C A 1$, and in the hilus. $C$, Hspb8 (red) shows colocalization with type 1 cells (small arrowhead). Also, Hspb8 colocalizes with type 2 cells identified by coexpression of Nestin-GFP (green) with double-cortin (blue). C2, High-power confocal images. C2' $-\mathbf{C 2}{ }^{\prime \prime}{ }^{\prime}$, Representative images of each protein marker (arrowheads). Also, Hspb8 colocalized with calretinin in some cells (D). D1, High-power images (arrowheads indicate Hspb8/calretinin double-positive immature neurons). $\boldsymbol{E}, \boldsymbol{E}$ 1, Representative images show that Hspb8 predominantly colocalizes with mature NeuN-positive neurons in the hippocampus. The colocalization is shown in high-power images (arrowhead; right). $A-D$, The molecular layer (ML), granular cell layer (GCL), and subgranular zone (SGZ). Scale bars: $A, B, 150 \mu \mathrm{m} ; C, 75 \mu \mathrm{m} ; \mathbf{C} 1,45 \mu \mathrm{m} ; \mathbf{D}, \boldsymbol{E}, 60 \mu \mathrm{m}$.

Control sequences did not affect cell differentiation $(p=0.44)$ or survival $(p=0.75)$ compared with the control group.

Given that overexpression of Hspb8 increased precursor cell differentiation and survival, that the silencing of the Hspb8 
A
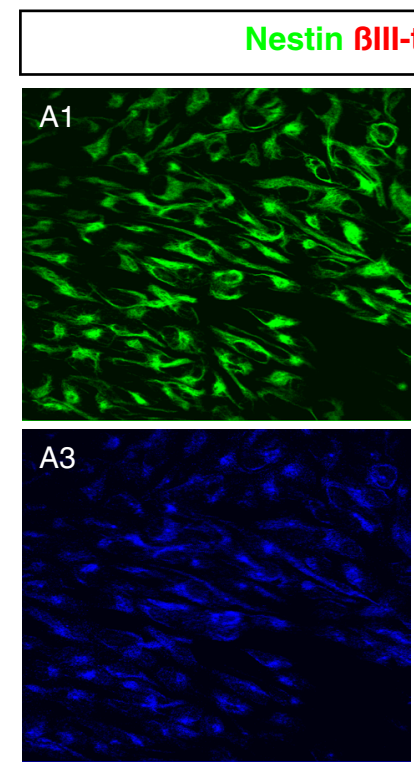

B

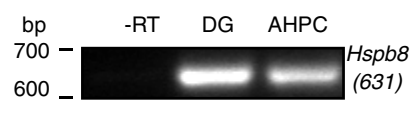

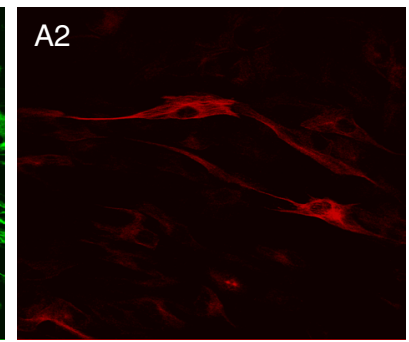

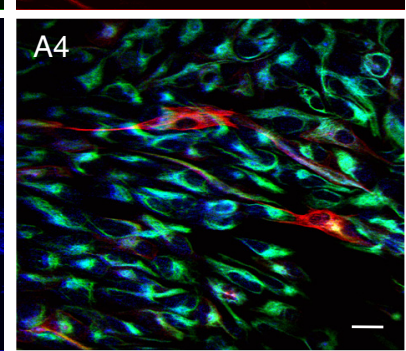

C

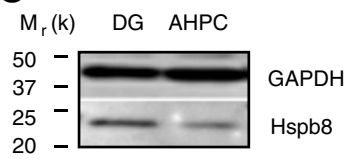

Figure 2. Hspb8 is expressed in adult hippocampal precursor cells and in the dentate gyrus of adult mice. $\boldsymbol{A}$, Precursor cells express $\mathrm{Hspb} 8$. Immunofluorescence staining depicting the expression of $\mathrm{Hspb} 8(\boldsymbol{A 3}$, blue) in precursor cells in culture. Precursor cells in culture were identified by nestin expression (A1, green) and $\beta$ Ill-tubulin (A2, red). Scale bar: $\boldsymbol{A 4}, 20 \mu \mathrm{m}$. $\boldsymbol{B}$, RT-PCR of Hspb8 using RNA derived from mouse adult precursor cells showed that the transcript is expressed in the precursor cells and in the dentate gyrus (DG). C, Expression of Hspb8 protein was also found in precursor cells (AHPC) and in the DG.

mRNA reduced neuronal differentiation and cell survival, and that during differentiation the levels of Hspb8 increased at 24, 48, and $96 \mathrm{~h}$ after induction of differentiation, Hspb8 appears to regulate survival and differentiation of new neurons in vitro.

\section{Hspb8 does not alter precursor cell proliferation in vivo}

Based on both our in vitro results and the expression of Hspb8 in the course of adult hippocampal neurogenesis in vivo, we next addressed the functional effects of $\mathrm{Hspb} 8$ on adult neurogenesis in vivo. We overexpressed $\mathrm{Hspb} 8$ using a lentiviral vector and stereotaxic injection. Proliferating cells were permanently labeled with three injections of BrdU, $6 \mathrm{~h}$ apart, at 3 weeks after viral injection (Fig. 6A). Proliferating transduced cells were identified by the codetection of both BrdU and GFP (Fig. 6B). Quantification of BrdU/GFP-labeled cells revealed that overexpression of Hspb8 or $\Delta \mathrm{Hspb8}$ did not change the number of proliferating cells in the dentate gyrus (LVGFP, $68 \pm 16$; LV-Hspb8, $60 \pm$ 13.86; LV- $\Delta$ Hspb8, $72 \pm 18 ; p=0.87$; Fig. $6 C)$.

\section{Hspb8 promotes survival and neurogenesis in vivo}

In contrast, overexpression of Hspb8 increased survival of newborn cells in the dentate gyrus. Surviving cells were labeled with BrdU 3 weeks after viral vector injection (Fig. 6D) and identified another 3 weeks later (Fig. 6E). Overexpression of Hspb8 significantly increased the number of BrdU/GFP-labeled cells compared with the control group (LVGFP; Fig. $6 F$ ). The number of surviving cells in the Hspb 8 transduced dentate gyrus increased significantly by $63 \%$ (LVGFP, $88 \pm 14.42$; LV-Hspb8, $144 \pm 17.66 ; p=0.022$; Fig. $6 F$ ).

A
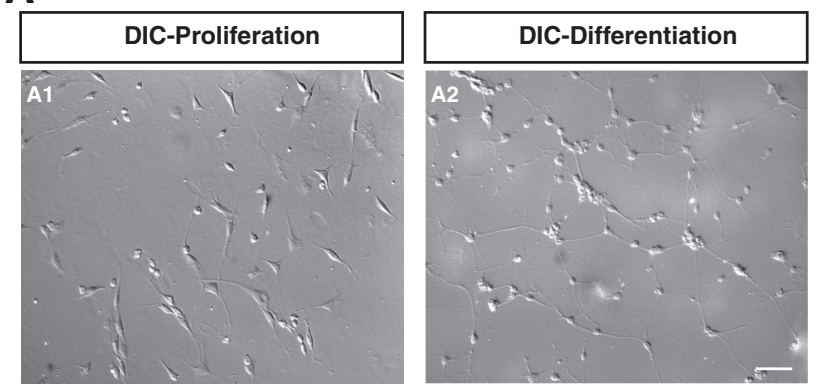

B

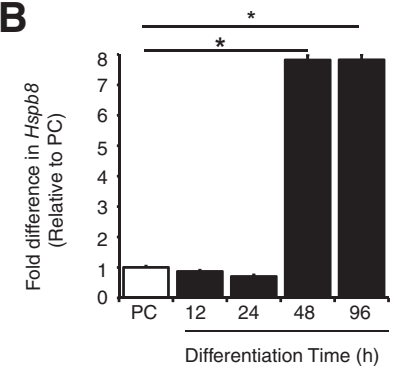

C

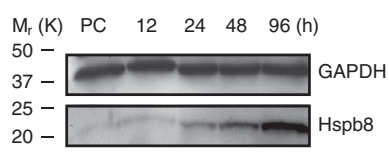

Figure 3. Expression changes of $\mathrm{Hspb8}$ during precursor cell differentiation in vitro. $\boldsymbol{A}$, Differential interference contrast (DIC) image of precursor cells cultured in the presence of growth factors is shown in $\boldsymbol{A} \mathbf{1}$, and precursor cells differentiated during $96 \mathrm{~h}$ are shown in $\boldsymbol{A 2}$. Images clearly show the morphological changes that occur before and after differentiation. Scale bar, $60 \mu \mathrm{m} . \boldsymbol{B}$, qRT-PCR of Hspb8 during the differentiation time course of precursor cells shows an increase in its expression level at 48 and $96 \mathrm{~h}$ after differentiation. Error bars indicate SEM. ${ }^{*} p<$ 0.0002 , PC versus 48 and $96 \mathrm{~h}$, respectively. C, The expression pattern of Hspb8 protein was analyzed by Western blot before and after induction of differentiation, indicating an increase in the protein level after $24 \mathrm{~h}$ of differentiation. GAPDH was used as loading control.

We also analyzed the phenotype of surviving BrdU/GFP cells after Hspb8 overexpression (Fig. 7A) and found a significant 2.33-fold increase in the fraction of cells that coexpressed BrdU/GFP and the neuronal marker, NeuN (LVGFP, $1 \pm 0.29$; LV-Hspb8, $2.33 \pm 0.60$; $p=0.026$, Fig. $7 B$ ). A similar but not statistically significant increase was seen in the number of BrdU/GFP/S100 $\beta+$ astrocytes (LVGFP, $1 \pm 0.58$; LV-Hspb8, $1.5 \pm 0.65 ; p=0.49$; Fig. 8).

\section{The $\alpha$ crystallin domain is involved in the proneurogenic} effects of Hspb8

Several small heat-shock proteins share a highly conserved functional domain, the $\alpha$-crystallin domain. Both Hspb8 and Hspb5 contain this domain. To study the potential role of the domain in the observed effects on neurogenesis, we overexpressed a truncated form of Hspb8, which lacks 120-145 residues of the $\alpha$-crystallin domain ( $\Delta \mathrm{Hspb8})$ in vitro and in vivo.

In cultured precursor cells, overexpression of $\Delta \mathrm{Hspb} 8$ prevented the effect of Hspb8 on neuronal differentiation ( 34\%, $p=0.001$; Fig. $4 C)$ and cell survival $(p=0.007$; Fig. $4 D)$.

Similarly, $\Delta$ Hspb8 did not show the effect on the survival of BrdU/GFP-labeled cells seen after transduction with Hspb8 in vivo (LV-Hspb8, $144 \pm 17.66 ; \mathrm{LV}-\Delta \mathrm{Hspb8}, 75 \pm 5.74 ; p=0.006$; Fig. $6 F)$.

Again, and consistent with the in vitro data (Fig. 4C), the effect of Hspb8 was specific to the survival of new neurons because $\Delta$ Hspb8 did not show this effect (LV-Hspb8, $2.33 \pm 0.60$; LV$\Delta$ Hspb8, $1 \pm 0.20 ; p=0.020$; Fig. $7 B$ ). In addition, the mean fraction of astrocytes appeared to be reduced by $50 \%$ after transduction with $\Delta \mathrm{Hspb} 8$, but this change did not meet the criterion of conventional statistical significance (LVGFP, $1 \pm 0.58$; LV$\Delta$ Hspb8, $0.5 \pm 0.29 ; p=0.41$; Fig. $8 B$ ). These results further 
A

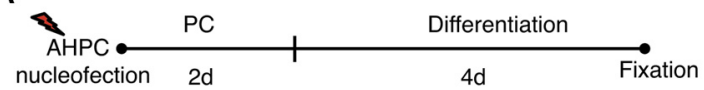

B
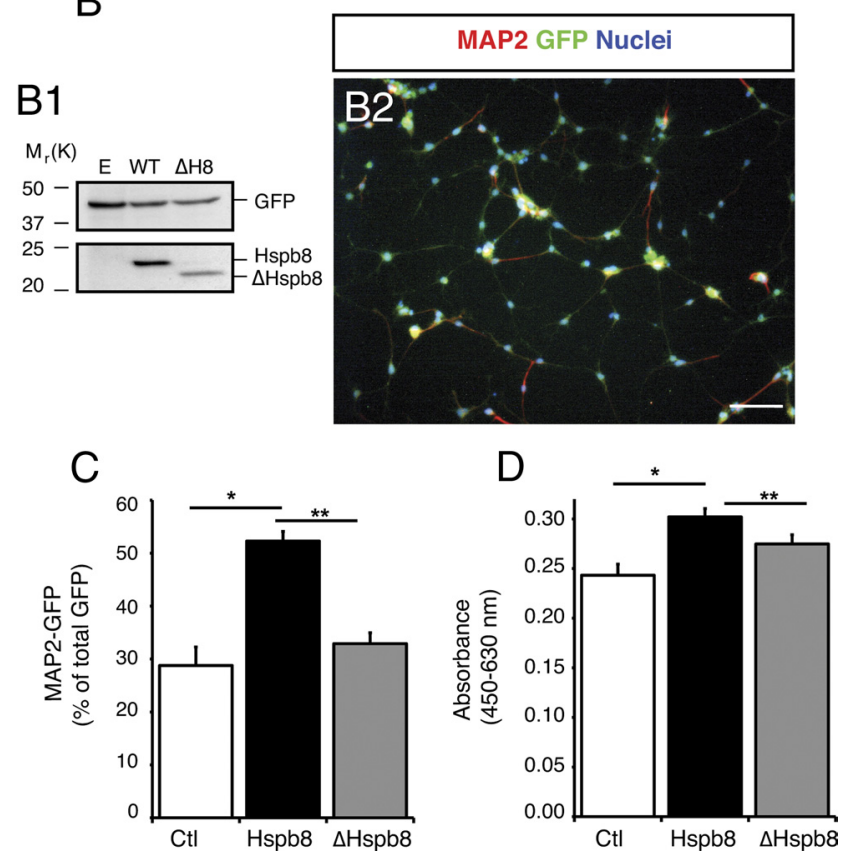

Figure 4. Overexpression of Hspb8 affects neuronal differentiation of precursor cells in vitro. $\boldsymbol{A}$, Experimental time line for $\mathrm{Hspb} 8$ effect on precursor cell (AHPC) differentiation. $\boldsymbol{B}$, Expression of Hspb8, $\Delta$ Hspb8, and GFP after nucleofection was verified by Western blot (B1). B2, Representative image of new neurons identified by the coexpression of GFP (green) and MAP2 (red). Nuclei were stained with DAPI (blue). Scale bar, $70 \mu \mathrm{m}$. C, Precursor cells expressing Hspb8 or $\Delta$ Hspb8 were differentiated during $4 \mathrm{~d}$. Quantification of MAP2/GFP neurons was done as described in Materials and Methods. There were significant differences in neuronal differentiation between groups. Hspb8 and $\Delta \mathrm{Hspb8}$ affect neuronal differentiation of precursor cells. Experiments were duplicated and repeated at least three times. Results represent the mean \pm SEM of total GFP. ${ }^{*} p=0.001$, control versus Hspb8 (Tukey's post hoc test after one-way ANOVA). ${ }^{* *} p=0.001$, Hspb8 versus $\Delta$ Hspb8 (Tukey's post hoc test after one-way ANOVA). D, Effect of Hspb8 overexpression on cell survival was done with Wst-1 assay, showing that Hspb8 significantly increased cell survival and that $\Delta \mathrm{Hspb8}$ affects this parameter. Wst- 1 analysis from six wells per group was performed three times. Error bars indicate SEM. ${ }^{*} p=0.001$, control versus Hspb8 (Tukey's post hoc test after one-way ANOVA). ${ }^{* *} p=0.007$, Hspb8 versus $\Delta$ Hspb8 (Tukey's post hoc test after one-way ANOVA).

corroborate the involvement of the $\alpha$-crystallin domain in the Hspb8-induced increase in survival of the newborn neurons.

\section{Hspb8 regulates survival of differentiated precursor cells via Akt signaling}

To get information about possible mechanisms by which Hspb8 exerts its effects on survival of precursor cells, we evaluated the activation of the key survival protein Akt, which is activated by Hspb8 in other cellular models (Sui et al., 2009). As previously reported, we also found that activated Akt (phospho-Akt) was downregulated in precursor cells that had been induced to differentiate (45\%; $p=0.001$; Fig. 9A, B) (Bracko et al., 2012). However, overexpression of Hspb8 caused a significant increase in the levels of phospho-Akt in differentiating precursor cells $(91 \%$; $p<$ 0.001; Fig. 9C). To confirm the involvement of Akt signaling pathway in the survival of differentiating hippocampal precursor cells induced by Hspb8, we incubated precursor cells with a specific inhibitor (LY294002) for phosphatidyl-inositol-3-kinase (PI3K), a protein that is upstream of Akt in the survival pathway (Sui et al., 2009). We found a significant decrease in the levels of
phospho-Akt in precursor cells that were transfected with Hspb8 after the incubation with the PI3K inhibitor (164\%; $p<0.001$; Fig. 9C). Additionally, we found that silencing $H s p b 8$ significantly decreased the activation of Akt compared with controls $(49 \% ; p<0.001$; Fig. 9D). These data suggest that Hspb8 acts at least partly via the Akt-dependent signaling pathway to regulate survival and differentiation of precursor cells.

Hspb8 regulates survival of differentiating precursor cells in a cell-autonomous manner

We also sought to determine whether Hspb8 exerts a cellautonomous or non-cell-autonomous effect on the survival of differentiating precursor cells. For these studies, we measured both proliferation and survival of wild-type precursor cells that were exposed to CM derived from precursor cells that overexpressed Hspb8 or had been transfected with siRNA-Hspb8 (Fig. $10 A)$. The extent of BrdU incorporation was similar across precursor cells treated with the CM collected from all groups $(p=$ 0.14; Fig. 10B). In a similar manner, the Wst- 1 assay did not show differences in the viability of proliferative cells $(p=0.24$; Fig. $10 C)$. Wild-type precursor cells exposed to CM and induced to differentiation did not show significant changes in survival measured with the BrdU and Wst- 1 assays ( $p=0.15$ and 0.22 , respectively; Fig. 10D,E). These studies revealed that the effects of Hspb8 on survival of differentiating precursor cells in vitro cannot be attributed to factors secreted by transfected precursor cells or by differentiated cells derived from transfected precursor cells. Thus, our data rather suggest a possible cell-autonomous mechanism, by which Hspb8 promotes survival and possibly the differentiation of precursor cells. In vivo additional or alternative indirect mechanisms might be active.

\section{Expression genetic analysis suggests an antiapoptotic role for $\mathrm{Hspb8}$}

We finally used our database of hippocampal gene expression in BXD mice to investigate the expression of $\mathrm{Hspb} 8$ and its variation in a genetic reference population (Overall et al., 2009). The BXD panel consists of mouse strains derived from inbreeding the progeny of an intercross between C57BL/6J and DBA/2J such that each resulting strain has a unique mix of both parental genotypes while being homozygous at every locus. The study described analyzed 69 of these strains, including the parental lines. The Affymetrix M430 version 2 microarray used in that study contains 3 probe sets targeting Hspb8, 1456434_x_at, 1417013_at, and 1417014_at. Because all three probe sets are of good quality (target-specific and expressed well in the hippocampus), we decided to use the first principal component (Hspb8-PC1, which explains $>90 \%$ of the expression variance in these probe sets) as a meta-trait for further analysis. To address the genetic control of $H s p b 8$ in the hippocampus, we performed QTL mapping with Hspb8-PC1 to identify genomic loci influencing transcript expression. We found that expression of the Hspb8 gene maps strongly to its own physical location in the genome (LOD score 17.5; Fig. 11A). This significant cis-QTL suggests that $H s p b 8$ is largely autoregulatory in the hippocampus and might exert a dominating effect in genetic networks in which it is involved.

We next searched for genes whose mRNA expression covaried with that of Hspb8 in the hippocampus under the premise that genes regulated in a similar pattern are more likely to be under common genetic control or acting in the same biochemical pathways. To do this, we calculated the Pearson correlation coefficient for Hspb8PC1 with every probe set in the expression dataset. The top 200 correlating probe sets were used for functional enrichment analysis 
A

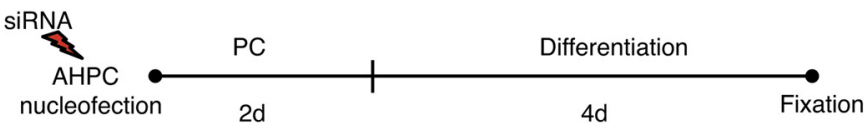

B

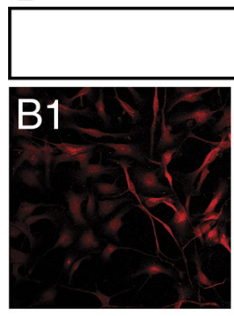

Hspb8 GFP Nuclei
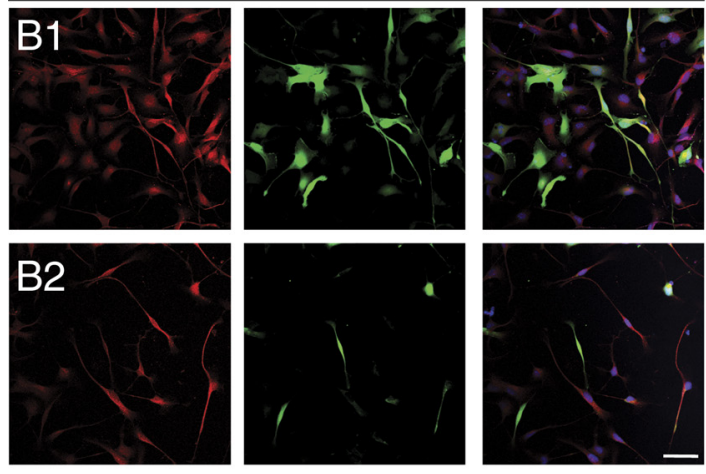

\section{C}

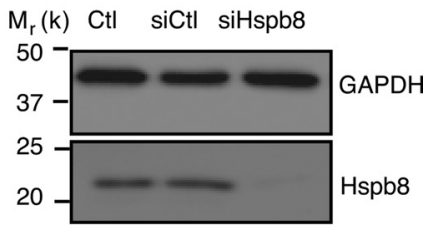

D
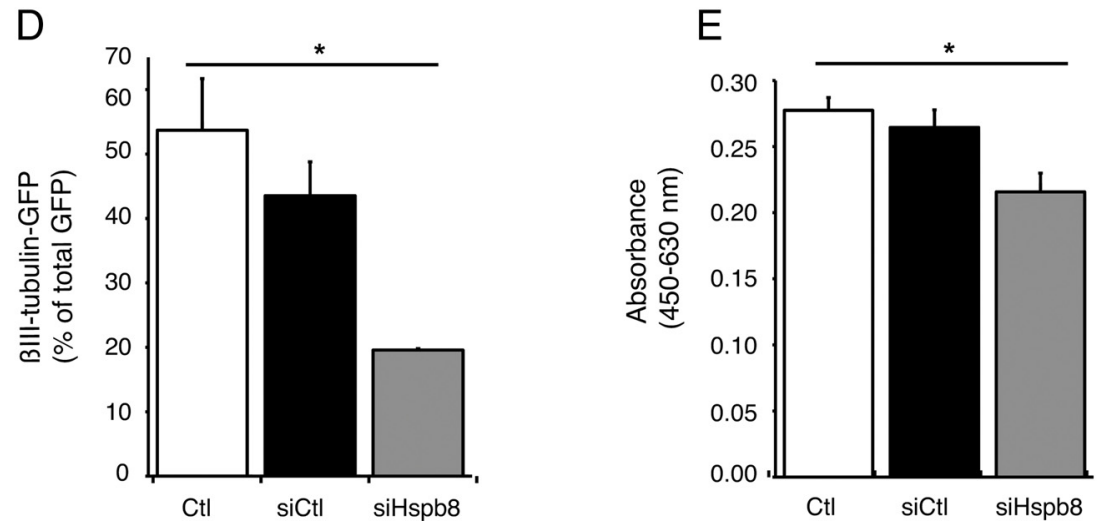

Figure 5. Knock-down of Hspb8 decreases neuronal differentiation and survival of precursor cells (AHPC) in vitro. A, Time line for the experiments in which $\mathrm{Hspb8}$ was silenced to evaluate its effects on neuronal differentiation and survival. $\boldsymbol{B}$, Immunofluorescence images of precursor cells nucleofected with control siRNA and $\mathrm{Hspb8}$ siRNA sequences are shown in $\boldsymbol{B} \mathbf{1}$ and $\mathbf{B 2}$, respectively. The decrease of Hspb8 was studied in cells that showed colocalization of the signals for Hspb8 (red) and GFP (green). B2, Merged images show cells with a decrease in Hspb8 expression without altered GFP expression after silencing. Scale bar, $30 \mu \mathrm{m}$. C, The effect of Hspb8 knock-down was analyzed by immunoblotting. Silencing of Hspb8 (si-Hspb8) decreased the expression of Hspb8, whereas control sequences (si-Ctl) did not affect Hspb8 expression levels. GAPDH was used as loading control. D, E, Hspb8 knock-down significantly affected neuronal differentiation and survival of precursor cells. Control sequences did not significantly affect either parameter. Quantification of $\beta$ III-tubulin/GFP neurons was performed as described in Materials and Methods. Experiments were as duplicates with three independent runs. Results represent the mean \pm SEM of total GFP. ${ }^{*} p=0.011$, Ctl versus si-Hspb8 (Tukey's post hoc test after one-way ANOVA); $p=0.44$, si-Ctl versus si-Hspb8 (Tukey's post hoc test after one-way ANOVA). $E$, Effect of Hspb8 overexpression on cell survival was also assessed with the Wst-1 assay. Wst- 1 analysis from six wells per group was performed three times. ${ }^{*} p=0.004$, Ctl versus si-Hspb8 (Tukey's post hoc test after one-way ANOVA); $p=0.75$, Ctl versus si-Ctl (Tukey's post hoc test after one-way ANOVA).

(data not shown). Because there is strong linkage disequilibrium at this locus, which means that adjacent genes will be correlated because of genotype and not necessarily because of their functional expression pattern, we ignored probe sets from the Hspb8 linkage block (defined as the interval in which markers correlated with an $r^{2}$ $>0.1$ with the markers adjacent to the Hspb8 gene). The remaining probe sets were split into genes positively or negatively correlating with Hspb8, and these two groups analyzed for enriched functional categories using the DAVID bioinformatics tool (Dennis et al., 2003; Huang da et al., 2009a, 2009b).

In the positively correlating group, we found enrichment for the categories "regulation of growth" (Hopx, Ddr1, Fgfrl, and $\mathrm{Ngf}$ ) and "regulation of apoptosis" (Bag3, Fgfrl, Ngf, and Ticam1) (Fig. 11B). The negatively correlating group showed enrich- ment for categories, including "intracellular signaling” (Arhgef9, Rab14, Rap2a, Gnaq, Plcb1, Gm266, Spred2, and Usp8), “apoptosis" (Bcl2l11, Fem1b, and Peg3) and "tissue morphogenesis" (Acvr1, Fem1b, and Serpinb5) (Fig. 11B).

We used the STRING online tool to identify a core network of interacting genes by submitting the gene names corresponding to the list of correlates described above and extending the network by adding the most-connected genes from the STRING database. The resulting core network (Fig. 11B) has been annotated to indicate the genes correlating with Hspb8-PC1. Positively correlating genes are highlighted green, negatively correlating genes in red. Two major clusters are apparent, one based around the nerve growth factor family of which several are positively correlated with Hspb8-PC1. Another group, positively interacting with the Hspb8/Bag3 complex, is composed of members of the apoptotic machinery.

\section{Discussion}

In the present study, we show that small heat-shock protein Hspb8 is highly expressed in the course of adult hippocampal neurogenesis in vivo and during differentiation of adult hippocampal precursor cells in vitro. Overexpression of Hspb8 increased the survival of newborn neurons in vitro and in vivo. Our data indicate that the $\alpha$-crystallin domain of Hspb8 is involved in the effects caused by Hspb8 and that Hspb8 promotes survival of new neurons in vitro through the activation of Akt suggesting, at least in vitro, a cell-autonomous mechanism.

Small heat shock proteins are differentially expressed in the brain of adult rodents (Quraishe et al., 2008; Kirbach and Golenhofen, 2011). Hspb8 is expressed in the hippocampus of adult mice and rats, but the expression of $H s p b 8$ mRNA is dependent on the developmental stage (Quraishe et al., 2008; Kirbach and Golenhofen, 2011). At embryonic and postnatal stages, $H s p b 8$ is modestly or not at all expressed in the rat hippocampus, whereas in the adult, expression of Hspb8 increases considerably (Kirbach and Golenhofen, 2011). In nonpathological human brain, small heat shock proteins are also expressed. In such studies, Hspb8 was expressed in neurons and also in blood vessels (Wilhelmus et al., 2006). We confirmed that Hspb8 is widely expressed, including on blood vessels, and is detectable in the neurogenic subgranular zone (Figs. 1 and $2 B, C)$. Hspb8 was increasingly expressed from type $2 \mathrm{~b}$ cells to mature neurons (Fig. 1). Moreover, in cultured precursor cells, $H s p b 8$ mRNA and protein were expressed (Fig. 2 B, C). These data first indicated that Hspb8 might be involved in survival and differentiation during adult neurogenesis in vivo, an idea supported by different lines of evidence suggesting an important role for Hspb8 in 
A

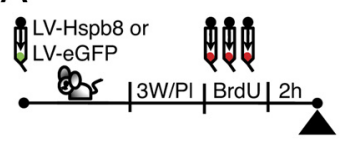

B

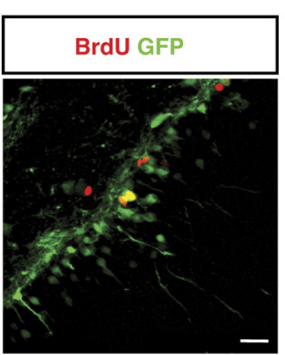

C

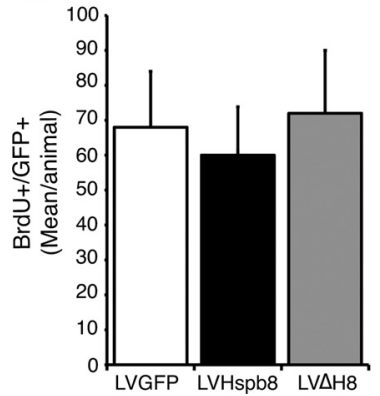

D

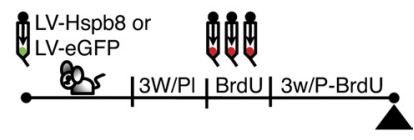

E

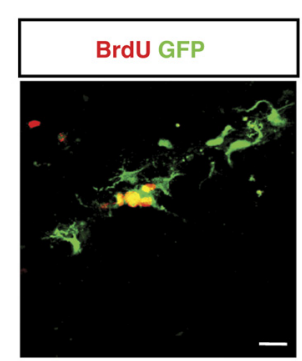

$\mathrm{F}$

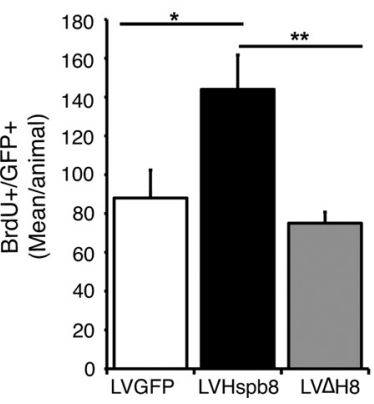

A

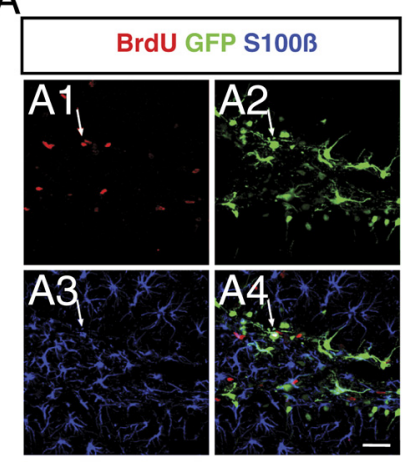

B

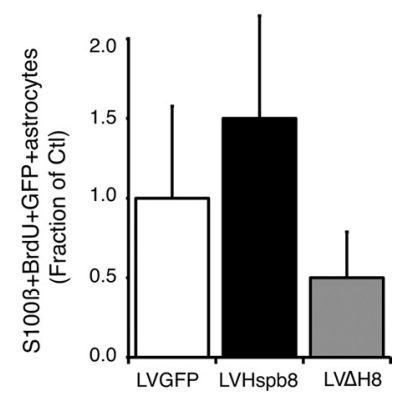

Figure 8. Hspb8 does not affect astrocytic differentiation in vivo. $A$, Astrocytic differentiation was assessed by counting BrdU-labeled cells ( $\boldsymbol{A} \mathbf{1}$, red) and $\mathrm{S} 100 \beta$-labeled cells ( $\boldsymbol{A} \mathbf{3}$, blue) $\mathrm{CO}^{-}$ expressing GFP ( $\boldsymbol{A} \mathbf{2}$, green) in the transduced areas (arrows). Scale bar, $40 \mu \mathrm{m}$. The merged image shows a triple-labeled cell for BrdU/ GFP/S100 $\beta$ (A4). B, Slight increase in BrdU/GFP/ $\mathrm{S} 100 \beta$-labeled astrocytes in the dentate gyrus of mice injected with LV-Hspb8 in relation to LV-GFP control mice (not significant). In contrast, the truncated LV- $\Delta$ Hspb8 decreased the fraction of astrocytes in relation to to LV-GFP control mice. $N=5$ or 6 mice per group. Error bars indicate SEM. $p=0.49$, LV-GFP versus LV-Hspb8 or LV-Hspb8 versus LV- $\Delta$ Hspb8 (Fisher's post hoc test after one-way ANOVA).

A

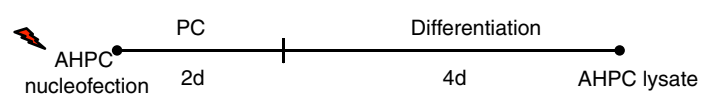

Figure 6. LV-mediated overexpression of LV-Hspb8 affects cell survival in vivo. A, Experimental design for the proliferation study in adult mice transduced with control viral vector (LVGFP), LV-Hspb8, or LV- $\Delta H$ spb8. After viral vector injection, proliferating cells were labeled by three sequential injections of BrdU $(50 \mathrm{mg} / \mathrm{kg})$. B, Cells in the proliferation phase were identified by the coexpression of BrdU/GFP in the transduced areas. Scale bar, $30 \mu \mathrm{m}$. C, Quantification of BrdU-labeled cells did not show significant changes in cell proliferation between LV-GFP, LV-Hspb8, and LV- $\Delta$ Hspb8 groups. D, Three weeks after viral vector injection (LVGFP, LV-Hspb8, or LV- $\Delta \mathrm{Hspb8}$ ), cells were labeled by three sequential injections of BrdU ( $30 \mathrm{mg} / \mathrm{kg}$ ). Surviving cells were quantified 3 weeks after the last BrdU administration. $\boldsymbol{E}$, Representative image of cells coexpressing BrdU/GFP in the transduced dentate gyrus. Scale bar, $30 \mu \mathrm{m} . \boldsymbol{F}$, Quantification of BrdU-labeled cells indicated an increase in cell survival caused by LV-Hspb8 compared with LV-GFP. However, the truncated LV- $\Delta$ Hspb8 did not affect cell survival caused by LV-Hspb8. $N=5$ or 6 mice per group. Error bars indicate SEM. ${ }^{*} p=0.022$, LV-GFP versus LV-Hspb8 (Fisher's post hoc test after one-way ANOVA). ${ }^{* *} p=0.006$, LV-Hspb8 versus LV$\Delta$ Hspb8 (Fisher's post hoc test after one-way ANOVA).
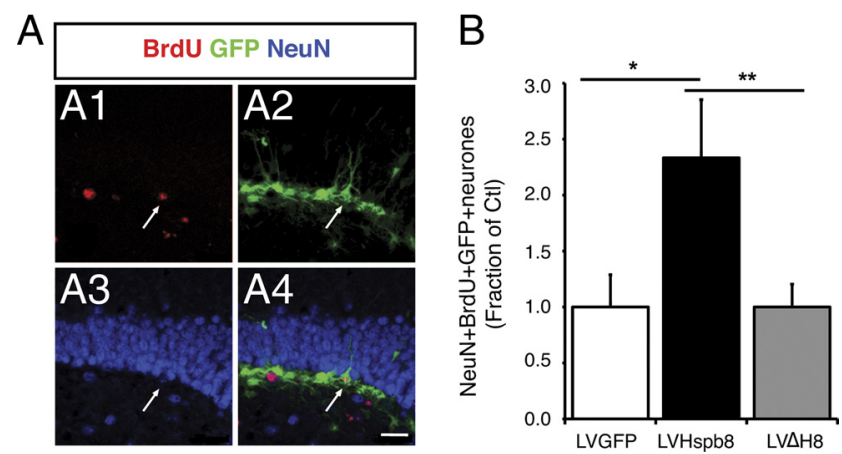

Figure 7. Hspb8 modulates neuronal differentiation in vivo. $A$, Neuronal differentiation was assessed by quantifying BrdU-labeled ( $\boldsymbol{A} \mathbf{1}$, red) and NeuN-labeled ( $\boldsymbol{A} \mathbf{3}$, blue) cells coexpressing GFP ( $\boldsymbol{A} \mathbf{2}$, green) in the transduced areas (arrows). Scale bar, $40 \mu \mathrm{m}$. The merged image shows a granule cell triple labeled for BrdU/NeuN/GFP (A4). B, Significant increase in BrdU/NeuN/GFPlabeled cells in the dentate gyrus of mice injected with LV-Hspb8 related to LV-GFP control mice. The truncated LV- $\Delta$ Hspb8 affects neuronal differentiation caused by LV-Hspb8. $N=5$ or 6 mice per group. Error bars indicate SEM. ${ }^{*} p=0.026, \mathrm{LV}$-GFP versus LV-Hspb8 (Fisher's post hoc test after one-way ANOVA). ${ }^{* *} p=0.020, \mathrm{LV}$-Hspb8 versus LV- $\Delta$ Hspb8 (Fisher's post hoc test after one-way ANOVA).
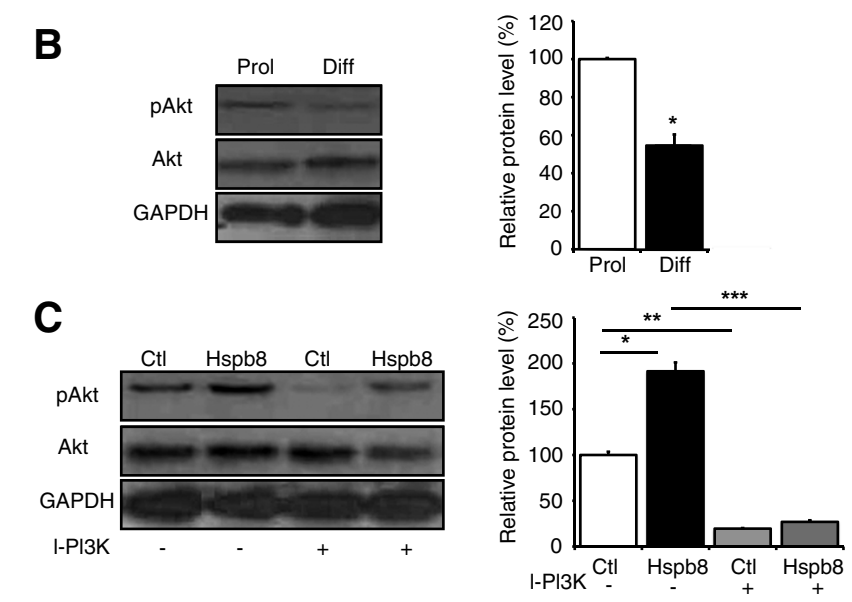

D
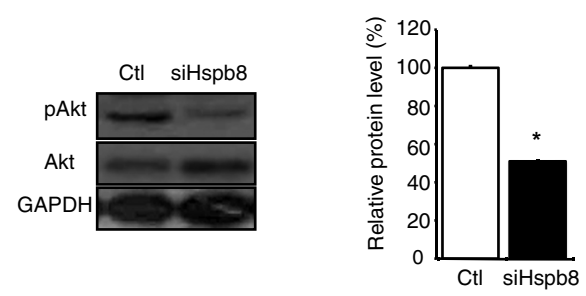

Figure 9. Overexpression of Hspb8 activates the Akt survival pathway during differentiation of precursor cells in vitro. $A$, Experimental time line for Hspb8 effects on precursor cell (AHPC) survival. B, Levels of phospho-Akt (p-Akt) decrease with differentiation of AHPC. C, Overexpression of Hspb8 increases levels of p-Akt, whereas cells that overexpressed Hspb8 and were incubated with PI3K inhibitor, LY294002 $10 \mu \mathrm{m}$ (I-PI3K) showed a decrease in levels of p-Akt. C, Knock-down of Hspb8 also decreased Akt phosphorylation. $\boldsymbol{B}-\boldsymbol{D}$, Representative autoradiograms and densitometric analysis of p-Akt. $\boldsymbol{B}$, Total Akt (unphosphorylated form). $\boldsymbol{D}$, GAPDH autoradiograms. Data were normalized to total Akt and GAPDH levels. Densitometric analysis represents the mean \pm SEM. $\boldsymbol{B}, p=0.001$. C, $p<0.001$. ${ }^{*}$ Control (Ctl) versus Hspb8. ${ }^{* *} \mathrm{Ctl}$ versus $\mathrm{CtI}+\mathrm{I}-\mathrm{PI} 3 \mathrm{~K} .{ }^{* * *} \mathrm{H}$ spb8 versus Hspb8 $+\mathrm{I-PI3K} . \boldsymbol{D}, p<0.001 .{ }^{*}$ Control (CtI) versus siHspb8 (Tukey's post hoc test after one-way ANOVA). 

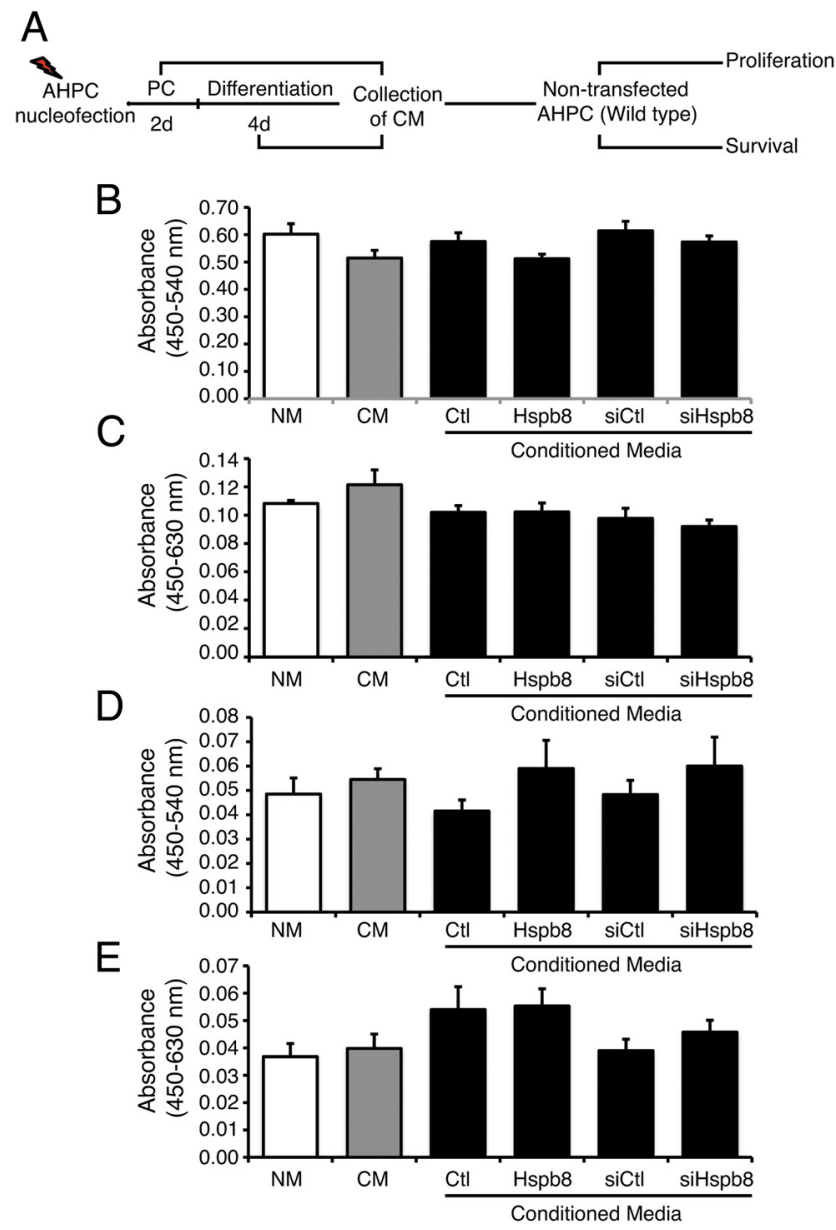

Figure 10. Soluble factors in CM from transfected precursor cells do not affect cell proliferation and survival of wild-type precursor cells in vitro. $\boldsymbol{A}$, Time line for experiments, in which $\mathrm{Hspb8}$ and siHspb8 were transfected to collect $C M$ for subsequent treatment of nontransfected (wild-type) precursor cells (AHPC). B, C, CM from Hspb8-and siHspb8-expressing precursor cells did not affect cell proliferation (BrdU) and viability (Wst-1) of wild-type cells. Similar results were obtained with cells treated with normal proliferation media (NM) or with CM obtained from nontransfected cells. Error bars indicate SEM. B, C, $p=0.14$ (BrdU) and $p=0.24$ (Wst- 1 ) (Tukey's post hoc test after one-way ANOVA). D, E, Wild-type precursor cells treated with CM from Hspb8- and siHspb8-expressing precursor cells did not lead to significant changes of survival. D, Wild-type precursor cells were prelabeled with BrdU before cells were switched to $C M$. Cells treated with NM or CM obtained from differentiated nontransfected cells did not show changes in cell survival. Error bars indicate SEM. D, E, $p=0.15$ (BrdU) and $p=0.22$ (Wst- 1 ) (Tukey's post hoc test after one-way ANOVA). The BrdU and Wst-1 analysis from six wells per group was performed three times each.

survival of different cell types, including neurons (Wang et al., 2004; Yew et al., 2005; Depre et al., 2006; Quraishe et al., 2008; Gurusamy et al., 2009; Sui et al., 2009; Karch and Borchelt, 2010; GonzalezMalerva et al., 2011; Kirbach and Golenhofen, 2011). Accordingly, we saw an increase in $H s p b 8$ mRNA and protein, when the differentiation of precursor cells was induced in vitro (Fig. $3 B, C$ ).

Overexpression of $\mathrm{Hspb} 8$ in precursor cells favored survival and neuronal differentiation. This effect was lost when the fragment comprising amino acid residues $120-145$ of the crystallin domain of Hspb8 was deleted.

To confirm these results in vivo, we overexpressed Hspb8 with a lentiviral vector. If injected into the hippocampus, these vectors predominantly $(<85 \%)$ transduce precursor cells and immature neurons rather than mature granule cells (van Hooijdonk et al., 2009). However, this is not exclusive because, as in our experiment at 1 or 5 weeks after viral injection, transduced cells were
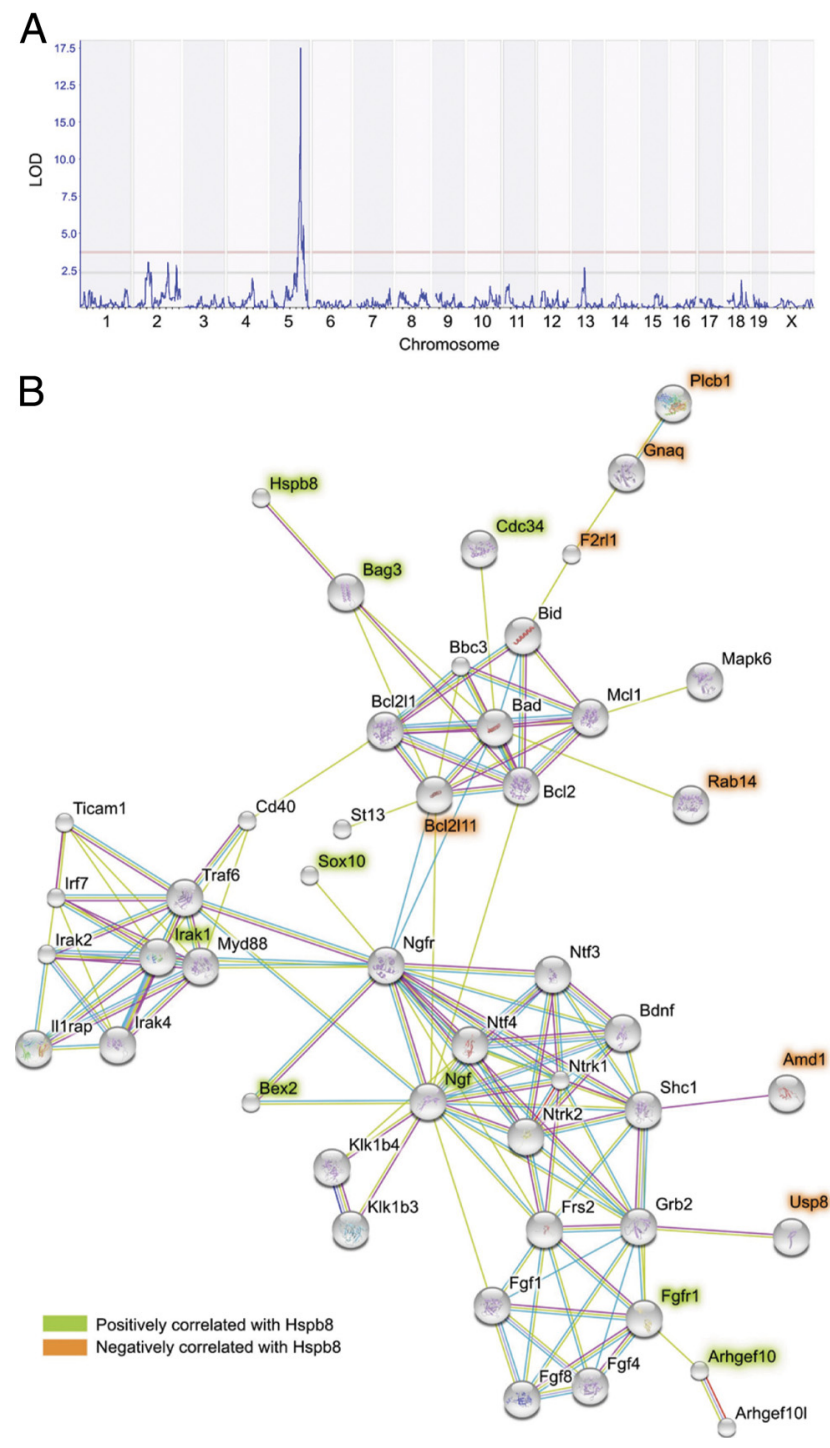

Figure 11. Genetic interactions of $H s p b 8$. A, Genomic association mapping of $H s p b 8 \mathrm{mRNA}$ expression. A composite trait comprised of the principal component of transcript expression measured by three microarray probes was mapped to the mouse genome. A very strong cis-QTL (quantitative trait locus at the same location as the $\mathrm{Hspb8}$ gene, blue trace) was highly significant (LOD 17.5), indicating that a sequence variant at this locus strongly affects $H$ spb8 gene expression. Gray and red horizontal lines indicate genome-wide significance at $p=0.63$ and $p=0.05$, respectively. $\boldsymbol{B}$, A subnetwork from the STRING database showing genes associated, directly or indirectly, with Hspb8. Colored connections indicate conceptual links between genes based on different sources of evidence, such as literature commentary, protein-protein binding, and microarray coexpression. Genes exhibiting expression correlation in a pertinent hippocampal microarray study are highlighted green for positive and red for inverse correlation.

found in the subgranular zone (van Hooijdonk et al., 2009; Fitzsimons et al., 2012). This might imply that the virus also infected the radial glia-like stem cells (type 1 cells).

The gain-of-function experiments confirmed that Hspb8 increased cell survival without affecting proliferation and promoted neuronal differentiation without significant changes in astrocytic differentiation. Hspb8-expression in astrocytes is consistent with a recent report (Seidel et al., 2012). Overexpressing Hspb8 with a truncated $\alpha$-crystallin domain affected the effects of wild-type Hspb8. Surprisingly, the truncated form of the $\alpha$-crystallin domain of Hspb8 that lacks the putative $\mathrm{N}$-myristoylation site, the $\mathrm{N}$-glycosylation, and protein kinase $\mathrm{C}$ motifs did not decrease baseline survival. However, in our con- 
struct, other regions remained intact, such as hydrophobic sequences and phosphorylation motifs for Erk that are also important for the chaperon action of Hspb8 (Irobi et al., 2004; Shemetov et al., 2011). Thus, we cannot exclude that other regions of Hspb8 are modulating or cooperating with the deleted portion of the $\alpha$-crystallin domain to promote survival. At the present time, it is not known which domain of Hspb8 is involved in protein interaction or whether Hspb8 is able to directly activate the kinases or promote the subcellular redistribution of proteins involved in survival. Further work is required to understand the contribution of each domain or regulatory site of Hspb8 to regulate adult hippocampal neurogenesis. However, silencing of Hspb8 confirmed that Hspb8 is relevant for cell survival and neuronal differentiation. This effect is also in line with reports that silencing Hspb8 caused cell death in MCF7 human breast adenocarcinoma cells (Gonzalez-Malerva et al., 2011).

Relatedly, missense mutations in residues of the crystallin domain of Hspb8 have caused neurodegeneration in cultured motor neurons without inducing cell death (Irobi et al., 2010). The $\alpha$-crystallin is mutated in distal hereditary motor neuropathy and Charcot-Marie-Tooth neuropathy type 2 . The effect of this mutation, however, is specific to motor neurons (Irobi et al., 2010). Our data indicate that the $\alpha$-crystallin nevertheless has more general effects on neuronal survival and differentiation. These data are also in accordance with studies, in which overexpression of Hspb8 protected cardiomyocytes whereas missense mutations in $\mathrm{Hspb} 8$ reduced survival (Sanbe et al., 2009; Carra et al., 2010).

Of note, abnormal expression of $\alpha \mathrm{B}$-crystallin (HSPB5) in oligodendrocytes was suspected to underlie a familial syndrome characterized by atrophy of the dentate gyrus, dementia, and congenital cataract (Hudson and Munoz, 1997). A link to adult neurogenesis was proposed and has been discussed (Hudson and Munoz, 2003). However, no mutation has been found in the crystallin gene. In the heart, a mutation to Hspb8 causes desmin-related cardiomyopathy, in which desmin and Hspb8 form damaging amyloid. Intriguingly, this process is blocked by Hspb8 (Sanbe et al., 2009).

Consequently, the mechanisms underlying the survivalpromoting effects of Hspb8 appear to be multifold and complex. In the heart, Hspb8 acts via the activation of key enzymes for cell survival, such as PI3K (Sui et al., 2009), accompanied by an increase in phosphorylated Akt. Akt is a serine/threonine protein kinase that acts downstream of PI3K and is involved in glucose metabolism, cell proliferation, apoptosis, transcription, cell migration, and dendritic growth through mTOR (Depre et al., 2006; Danan et al., 2007; Kim et al., 2009, 2012; Sui et al., 2009). Future studies should examine direct or indirect effects of Hspb8 on other aspects of adult neurogenesis, including neurite growth and maturation and the functional integration of the newborn cells.

Hspb8 apparently directly binds to Akt and 5AMP-activated protein kinase for promoting the nuclear translocation of both proteins to promote survival (Depre et al., 2006). Here, we show that Hspb8 acts via PI3K to activate Akt for promoting the survival of differentiating precursor cells (Fig. 9C), which is in line with the assumed role for Akt in modulating survival in the brain (Brazil et al., 2004). In addition, our in vitro data suggest that the effect of Hspb8 might be based on a cell-autonomous mechanism because soluble factors contained in CM from precursor cells or differentiated precursor cells transfected with Hspb8 or with siRNA oligonucleotides for Hspb8 did not affect cell proliferation and survival (Fig. 10). However, our study does not rule out changes mediated through Hspb8-dependent cell-cell interactions in vivo. Given that Hspb8 is also expressed in blood vessels
(Fig. 1), the in vivo experiments cannot fully exclude an extrinsic role for Hspb8. The vasculature presumably plays an important role for neurogenesis, given that the vascular niche presumably provides many regulators that could act as extrinsic cues for neurogenesis (Palmer et al., 2000). At least for the songbird system, such regulatory link is well established (Louissant et al., 2002).

Moreover, Hspb8 inhibits proapoptotic effectors, such as Bad, Foxo, and glycogen synthase kinase- $3 \beta$, and activates antiapoptotic effectors as endothelial NO synthase isoforms (Depre et al., 2006). In cardiomyocytes treated with HSP inducer geranylgeranylacetone, Hspb8 inhibited the activation of caspase-3 (Sanbe et al., 2009). Together, these data suggest multiple potential mechanisms and not a single mode of action.

Thus, our findings related to the prosurvival effect of Hspb8 are consistent with recent reports indicating that the promotion of survival is an important step in the stimulation of neurogenesis (Pieper et al., 2010; Sahay et al., 2011), which might consequently enhance the functionality of the dentate gyrus (Sahay et al., 2011).

In addition, we used our database of hippocampal gene expression in BXD mice to identify potential target genes in our system (Overall et al., 2009). This approach makes use of genetically determined variation in transcript expression to detect covariance as indicator of a shared direct or indirect causality.

Indeed, Hspb8 expression positively correlated with genes involved in cell growth (Hopx, Ddr1, Fgfr1, and Ngf). Some of these genes, such as Ngf, increase Bcl and decrease Bax to prevent neuronal apoptosis (Deckwerth et al., 1996; Putcha et al., 1999; Arthur et al., 2006). Consequently, Hspb8 also positively correlated with other genes regulating apoptosis, such as Ticam1 and Bag3. The correlation between Hspb8 and Bag3 is particularly interesting in the context of adult neurogenesis given that recent studies indicated that Bag3 binds to Hspb8 to promote autophagy in different cell types (Carra et al., 2008a, 2008b; Carra, 2009; Fuchs et al., 2009; Gurusamy et al., 2009; McCollum et al., 2009; Arndt et al., 2010). Autophagia is a catabolic process involving lysosomal degradation and recycling of cytoplasmic constituents and occurs at low basal levels in all tissues. Autophagia contributes to tissue homeostasis (Levine and Kroemer, 2008) and is rapidly upregulated after damage. Nevertheless, in some circumstances, the upregulation of autophagy protects against the onset of apoptosis (Levine and Kroemer, 2008).

Similar to the antiamyloidogenic effect of Hspb8 in cardiomyocytes, a prevention of $\beta$-sheet formation in Alzheimer disease and Huntingin aggregation in Huntington disease have also been suggested (Wilhelmus et al., 2006; Carra et al., 2009).

A related small heat-shock protein, $\mathrm{Hspb} 4(\mathrm{Cry} \alpha \mathrm{A})$ is expressed in a highly region-specific manner and was discovered to be an essential survival factor for the dopaminergic interneurons in the olfactory bulb (Ninkovic et al., 2010). It thus seems that crystallins play important roles in neuronal survival, with different genes exerting more or less specific functions in different populations of cells. In conclusion, we here provide evidence that Hspb8 acts as an important factor in regulating survival in the adult hippocampal neurogenesis through the activation of a key survival pathway that involves PI3K and Akt.

\section{References}

Arndt V, Dick N, Tawo R, Dreiseidler M, Wenzel D, Hesse M, Fürst DO, Saftig P, Saint R, Fleischmann BK, Hoch M, Höhfeld J (2010) Chaperone-assisted selective autophagy is essential for muscle maintenance. Curr Biol 20:143148. CrossRef Medline

Arthur DB, Georgi S, Akassoglou K, Insel PA (2006) Inhibition of apoptosis by P2Y2 receptor activation: novel pathways for neuronal survival. J Neurosci 26:3798-3804. CrossRef Medline 
Babu H, Ramírez-Rodríguez G, Fabel K, Bischofberger J, Kempermann G (2009) Synaptic network activity induces neuronal differentiation of adult hippocampal precursor cells through BDNF signaling. Front Neurosci 3:49. CrossRef Medline

Babu H, Claasen JH, Kannan S, Rünker AE, Palmer T, Kempermann G (2011) A protocol for isolation and enriched monolayer cultivation of neural precursor cells from mouse dentate gyrus. Front Neurosci 5:89. CrossRef Medline

Bracko O, Singer T, Aigner S, Knobloch M, Winner B, Ray J, Clemenson GD Jr, Suh H, Couillard-Despres S, Aigner L, Gage FH, Jessberger S (2012) Gene expression profiling of neural stem cells and their neuronal progeny reveals IGF2 as a regulator of adult hippocampal neurogenesis. J Neurosci 10:3376-3387. CrossRef Medline

Brazil DP, Yang ZZ, Hemmings BA (2004) Advances in protein kinase B signalling: AKTion on multiple fronts. Trends Biochem Sci 29:233-242. CrossRef Medline

Carra S (2009) The stress-inducible HspB8-Bag3 complex induces the eIF2alpha kinase pathway: implications for protein quality control and viral factory degradation? Autophagy 5:428-429. CrossRef Medline

Carra S, Seguin SJ, Landry J (2008a) HspB8 and Bag3: a new chaperone complex targeting misfolded proteins to macroautophagy. Autophagy 4:237-239. Medline

Carra S, Seguin SJ, Lambert H, Landry J (2008b) HspB8 chaperone activity toward poly $(\mathrm{Q})$-containing proteins depends on its association with Bag3, a stimulator of macroautophagy. J Biol Chem 283:1437-1444. CrossRef Medline

Carra S, Brunsting JF, Lambert H, Landry J, Kampinga HH (2009) HspB8 participates in protein quality control by a non-chaperone-like mechanism that requires eIF2 $\alpha$ phosphorylation. J Biol Chem 284:5523-5532. CrossRef Medline

Carra S, Boncoraglio A, Kanon B, Brunsting JF, Minoia M, Rana A, Vos MJ, Seidel K, Sibon OC, Kampinga HH (2010) Identification of the Drosophila ortholog of HSPB8: implication of HSPB8 loss of function in protein folding diseases. J Biol Chem 285:37811-37822. CrossRef Medline

Cleveland DW, Fischer SG, Kirschner MW, Laemmli UK (1977) Peptide mapping by limited proteolysis in sodium dodecyl sulfate and analysis by gel electrophoresis. J Biol Chem 252:1102-1106. Medline

Crippa V, Sau D, Rusmini P, Boncoraglio A, Onesto E, Bolzoni E, Galbiati M, Fontana E, Marino M, Carra S, Bendotti C, De Biasi S, Poletti A (2010) The small heat shock protein $\mathrm{B} 8(\mathrm{HspB} 8)$ promotes autophagic removal of misfolded proteins involved in amyotrophic lateral sclerosis (ALS). Hum Mol Genet 19:3440-3456. CrossRef Medline

Danan IJ, Rashed ER, Depre C (2007) Therapeutic potential of H11 kinase for the ischemic heart. Cardiovasc Drug Rev 25:14-29. CrossRef Medline

David JC, Boelens WC, Grongnet JF (2006) Up-regulation of heat shock protein HSP 20 in the hippocampus as an early response to hypoxia of the newborn. J Neurochem 99:570-581. CrossRef Medline

Deckwerth TL, Elliott JL, Knudson CM, Johnson EM Jr, Snider WD, Korsmeyer SJ (1996) BAX is required for neuronal death after trophic factor deprivation and during development. Neuron 17:401-411. CrossRef Medline

Dennis G Jr, Sherman BT, Hosack DA, Yang J, Gao W, Lane HC, Lempicki RA (2003) DAVID: Database for Annotation, Visualization, and Integrated Discovery. Genome Biol 4:P3. CrossRef Medline

Depre C, Wang L, Sui X, Qiu H, Hong C, Hedhli N, Ginion A, Shah A, Pelat M, Bertrand L, Wagner T, Gaussin V, Vatner SF (2006) H11 kinase prevents myocardial infarction by preemptive preconditioning of the heart. Circ Res 98:280-288. CrossRef Medline

Fitzsimons CP, van Hooijdonk LWA, Schouten M, Zalachoras I, Brinks V, Zheng T, Schouten TG, Saaltink DJ, Dijkmans T, Steindler DA, Verhaagen J, Verbeek FJ, Lucassen P, de Kloet ER, Meijer OC, Karst H, Joels M, Oitzl MS, Vreugdenhil E (2012) Knockdown of the glucocorticoid receptor alters functional integration of newborn neurons in the adult hippocampus and impairs fear-motivated behavior. Mol Psych Advance online publication. Retrieved August 28, 2012. doi:10.1038/mp.2012.123. CrossRef Medline

Fuchs M, Poirier DJ, Seguin SJ, Lambert H, Carra S, Charette SJ, Landry J (2009) Identification of the key structural motifs involved in HspB8/ HspB6-Bag3 interaction. Biochem J 425:245-255. CrossRef Medline

Galea LA (2008) Gonadal hormone modulation of neurogenesis in the den- tate gyrus of adult male and female rodents. Brain Res Rev 57:332-341. CrossRef Medline

Geraerts M, Eggermont K, Hernandez-Acosta P, Garcia-Verdugo JM, Baekelandt V, Debyser Z (2006) Lentiviral vectors mediate efficient and stable gene transfer in adult neural stem cells in vivo. Hum Gene Ther 17:635650. CrossRef Medline

Gonzalez-Malerva L, Park J, Zou L, Hu Y, Moradpour Z, Pearlberg J, Sawyer J, Stevens H, Harlow E, LaBaer J (2011) High-throughput ectopic expression screen for tamoxifen resistance identifies an atypical kinase that blocks autophagy. Proc Natl Acad Sci U S A 108:2058-2063. CrossRef Medline

Gurusamy N, Lekli I, Gherghiceanu M, Popescu LM, Das DK (2009) BAG-1 induces autophagy for cardiac cell survival. Autophagy 5:120-121. CrossRef Medline

Hagemann TL, Boelens WC, Wawrousek EF, Messing A (2009) Suppression of GFAP toxicity by $\alpha \mathrm{B}$-crystallin in mouse models of Alexander disease. Human Mol Genet 18:1190-1199. CrossRef Medline

Huang da W, Sherman BT, Lempicki RA (2009a) Systematic and integrative analysis of large gene lists using DAVID bioinformatics resources. Nat Protoc 4:44-57. CrossRef Medline

Huang da W, Sherman BT, Zheng X, Yang J, Imamichi T, Stephens R, Lempicki RA (2009b) Extracting biological meaning from large gene lists with DAVID. Curr Protoc Bioinformatics 13:11. CrossRef Medline

Hudson AJ, Munoz DG (1997) A familial syndrome of congenital cataract, mental impairment, and dentate gyrus atrophy. Ann Neurol 41:512-520. CrossRef Medline

Hudson AJ, Munoz DG (2003) Familial dementia with dentate atrophy and failure of neurogenesis. Ann Neurol 53:420-421; author reply 421. CrossRef Medline

Irobi J, Van Impe K, Seeman P, Jordanova A, Dierick I, Verpoorten N, Michalik A, De Vriendt E, Jacobs A, Van Gerwen V, Vennekens K, Mazanec R, Tournev I, Hilton-Jones D, Talbot K, Kremensky I, Van Den Bosch L, Robberecht W, Van Vandekerckhove J, Van Broeckhoven C, et al (2004) Hot-spot residue in small heat-shock protein 22 causes distal motor neuropathy. Nat Genet 36:597-601. CrossRef Medline

Irobi J, Almeida-Souza L, Asselbergh B, De Winter V, Goethals S, Dierick I, Krishnan J, Timmermans JP, Robberecht W, De Jonghe P, Van Den Bosch L, Janssens S, Timmerman V (2010) Mutant HSPB8 causes motor neuron-specific neurite degeneration. Hum Mol Genet 19:3254-3265. CrossRef Medline

Jessberger S, Aigner S, Clemenson GD Jr, Toni N, Lie DC, Karalay O, Overall R, Kempermann G, Gage FH (2008) Cdk5 regulates accurate maturation of newborn granule cells in the adult hippocampus. PLoS Biol 6:e272. CrossRef Medline

Karch CM, Borchelt DR (2010) An examination of $\alpha$ B-crystallin as a modifier of SOD1 aggregate pathology and toxicity in models of familial amyotrophic lateral sclerosis. J Neurochem 113:1092-1100. CrossRef Medline

Kempermann G, Jessberger S, Steiner B, Kronenberg G (2004) Milestones of neuronal development in the adult hippocampus. Trends Neurosci 27:447-452. CrossRef Medline

Kempermann G, Chesler EJ, Lu L, Williams RW, Gage FH (2006) Natural variation and genetic covariance in adult hippocampal neurogenesis. Proc Natl Acad Sci U S A 103:780-785. CrossRef Medline

Kim JY, Duan X, Liu CY, Jang MH, Guo JU, Pow-anpongkul N, Kang E, Song H, Ming GL (2009) DISC regulates new neuron development in the adult brain via modulation of AKT-mTOR signaling through kiaa1212. Neuron 63:761-773. CrossRef Medline

Kim JY, Liu CY, Zhang F, Duan X, Wen Z, Song J, Feighery E, Lu B, Rujescu D, St Clair D, Christian K, Callicott JH, Weinberger DR, Song H, Ming GL (2012) Interplay between DISC1 and GABA signaling regulates neurogenesis in mice and risk for schizophrenia. Cell 148:1051-1064. CrossRef Medline

Kirbach BB, Golenhofen N (2011) Differential expression and induction of small heat shock proteins in rat brain and cultured hippocampal neurons. J Neurosci Res 89:162-175. CrossRef Medline

Koo JW, Russo SJ, Ferguson D, Nestler EJ, Duman RS (2010) Nuclear factor $-\kappa \mathrm{B}$ is a critical mediator of stress-impaired neurogenesis and depressive behavior. Proc Natl Acad Sci U S A 107:2669-2674. CrossRef Medline

Leuner B, Caponiti JM, Gould E (2012) Oxytocin stimulates adult neuro- 
genesis even under conditions of stress and elevated glucocorticoids. Hippocampus 22:861-868. CrossRef Medline

Levine B, Kroemer G (2008) Autophagy in the pathogenesis of disease. Cell 132:27-42. CrossRef Medline

Lie DC, Colamarino SA, Song HJ, Désiré L, Mira H, Consiglio A, Lein ES, Jessberger S, Lansford H, Dearie AR, Gage FH (2005) Wnt signalling regulates adult hippocampal neurogenesis. Nature 437:1370-1375. CrossRef Medline

Louissant A Jr, Rao S, Leventhal C, Goldman SA (2002) Coordinated interaction of angiogenesis and neurogenesis in the adult songbird brain. Neuron 34:945-960. CrossRef Medline

Mastrangelo MA, Sudol KL, Narrow WC, Bowers WJ (2009) Interferon- $\gamma$ differentially affects Alzheimer's disease pathologies and induces neurogenesis in triple transgenic-AD mice. Am J Pathol 175:2076-2088. CrossRef Medline

McCollum AK, Casagrande G, Kohn EC (2009) Caught in the middle: the role of Bag3 in disease. Biochem J 425:el-e3. CrossRef Medline

Mueller AD, Pollock MS, Lieblich SE, Epp JR, Galea LA, Mistlberger RE (2008) Sleep deprivation can inhibit adult hippocampal neurogenesis independent of adrenal stress hormones. Am J Physiol Regul Integr Comp Physiol 294:R1693-R1703. CrossRef Medline

Ninkovic J, Pinto L, Petricca S, Lepier A, Sun J, Rieger MA, Schroeder T, Cvekl A, Favor J, Götz M (2010) The transcription factor Pax6 regulates survival of dopaminergic olfactory bulb neurons via crystallin $\alpha$ A. Neuron 68:682-694. CrossRef Medline

Overall RW, Kempermann G, Peirce J, Lu L, Goldowitz D, Gage FH, Goodwin S, Smit AB, Airey DC, Rosen GD, Schalkwyk LC, Sutter TR, Nowakowski RS, Whatley S, Williams RW (2009) Genetics of the hippocampal transcriptome in mouse: a systematic survey and online neurogenomics resource. Front Neurosci 3:55. CrossRef Medline

Palmer TD, Willhoite AR, Gage FH (2000) Vascular niche for adult hippocampal neurogenesis. J Comp Neurol 425:479-494. CrossRef Medline

Pawluski JL, Brummelte S, Barha CK, Crozier TM, Galea LA (2009) Effects of steroid hormones on neurogenesis in the hippocampus of the adult female rodent during the estrous cycle, pregnancy, lactation and aging. Front Neuroendocrinol 30:343-357. CrossRef Medline

Peng Q, Masuda N, Jiang M, Li Q, Zhao M, Ross CA, Duan W (2008) The antidepressant sertraline improves the phenotype, promotes neurogenesis and increases BDNF levels in the R6/2 Huntington's disease mouse model. Exp Neurol 210:154-163. CrossRef Medline

Perera TD, Coplan JD, Lisanby SH, Lipira CM, Arif M, Carpio C, Spitzer G, Santarelli L, Scharf B, Hen R, Rosoklija G, Sackeim HA, Dwork AJ (2007) Antidepressant-induced neurogenesis in the hippocampus of adult nonhuman primates. J Neurosci 27:4894-4901. CrossRef Medline

Pieper AA, Xie S, Capota E, Estill SJ, Zhong J, Long JM, Becker GL, Huntington P, Goldman SE, Shen CH, Capota M, Britt JK, Kotti T, Ure K, Brat DJ, Williams NS, MacMillan KS, Naidoo J, Melito L, Hsieh J, De Brabander J, Ready JM, McKnight SL (2010) Discovery of a proneurogenic, neuroprotective chemical. Cell 142:39-51. CrossRef Medline

Pinnock SB, Herbert J (2008) Brain-derived neurotropic factor and neurogenesis in the adult rat dentate gyrus: interactions with corticosterone. Eur J Neurosci 27:2493-2500. CrossRef Medline

Putcha GV, Deshmukh M, Johnson EM Jr (1999) BAX translocation is a critical event in neuronal apoptosis: regulation by neuroprotectants, BCL-2, and caspases. J Neurosci 19:7476-7485. Medline

Quraishe S, Asuni A, Boelens WC, O'Connor V, Wyttenbach A (2008) Expression of the small heat shock protein family in the mouse CNS: differential anatomical and biochemical compartmentalization. Neuroscience 153:483-491. CrossRef Medline

Ramírez-Rodríguez G, Klempin F, Babu H, Benítez-King G, Kempermann G (2009) Melatonin modulates cell survival of new neurons in the hippocampus of adult mice. Neuropsychopharmacology 34:2180-2191. CrossRef Medline
Ramírez-Rodríguez G, Ortíz-López L, Domínguez-Alonso A, Benítez-King GA, Kempermann G (2011) Chronic treatment with melatonin stimulates dendrite maturation and complexity in adult hippocampal neurogenesis of mice. J Pineal Res 50:29-37. CrossRef Medline

Rossi C, Angelucci A, Costantin L, Braschi C, Mazzantini M, Babbini F, Fabbri ME, Tessarollo L, Maffei L, Berardi N, Caleo M (2006) Brainderived neurotrophic factor (BDNF) is required for the enhancement of hippocampal neurogenesis following environmental enrichment. Eur J Neurosci 24:1850-1856. CrossRef Medline

Sahay A, Scobie KN, Hill AS, O'Carroll CM, Kheirbek MA, Burghardt NS, Fenton AA, Dranovsky A, Hen R (2011) Increasing adult hippocampal neurogenesis is sufficient to improve pattern separation. Nature 472:466-470. CrossRef Medline

Sanbe A, Daicho T, Mizutani R, Endo T, Miyauchi N, Yamauchi J, Tanonaka K, Glabe C, Tanoue A (2009) Protective effect of geranylgeranylacetone via enhancement of HSPB8 induction in desmin-related cardiomyopathy. PLoS One 4:e5351. CrossRef Medline

Seidel K, Vinet J, Dunnen WF, Brunt ER, Meister M, Boncoraglio A, Zijlstra MP, Boddeke HW, Rub U, Kampinga HH, Carra S (2012) The Hspb8BAG3 chaperone complex is upregulated in astrocytes in the human brain affected by protein aggregation diseases. Neurophatol Appl Neurobiol 1:39-53. CrossRef Medline

Shemetov AA, Seit-Nebi AS, Gusev NB (2011) Phosphorylation of human small heat shock protein HspB8 (Hsp22). Mol Cell Biochem 1:47-55. CrossRef Medline

Snel B, Lehmann G, Bork P, Huynen MA (2000) STRING: a web-server to retrieve and display the repeatedly occurring neighbourhood of a gene. Nucleic Acids Res 28:3442-3444. CrossRef Medline

Sui X, Li D, Qiu H, Gaussin V, Depre C (2009) Activation of the bone morphogenetic protein receptor by $\mathrm{H} 11$ kinase/Hsp22 promotes cardiac cell growth and survival. Circ Res 104:887-895. CrossRef Medline

Szklarczyk D, Franceschini A, Kuhn M, Simonovic M, Roth A, Minguez P, Doerks T, Stark M, Muller J, Bork P, Jensen LJ, von Mering C (2011) The STRING database in 2011: functional interaction networks of proteins, globally integrated and scored. Nucleic Acids Res 39:D561-D568. CrossRef Medline

Tang D, Khaleque MA, Jones EL, Theriault JR, Li C, Wong WH, Stevenson MA, Calderwood SK (2005) Expression of heat shock proteins and heat shock protein messenger ribonucleic acid in human prostate carcinoma in vitro and in tumors in vivo. Cell Stress Chaperones 10:46-58. CrossRef Medline

van Hooijdonk LW, Ichwan M, Dijkmans TF, Schouten TG, de Backer MW, Adan RA, Verbeek FJ, Vreugdenhil E, Fitzsimons CP (2009) Lentivirusmediated transgene delivery to the hippocampus reveals sub-field specific differences in expression. BMC Neurosci 10:2. CrossRef Medline

Wang L, Zajac A, Hedhli N, Depre C (2004) Increased expression of H11 kinase stimulates glycogen synthesis in the heart. Mol Cell Biochem 265: 71-78. CrossRef Medline

Wilhelmus MM, Boelens WC, Otte-Höller I, Kamps B, Kusters B, MaatSchieman ML, de Waal RM, Verbeek MM (2006) Small heat shock protein HspB8: its distribution in Alzheimer's disease brains and its inhibition of amyloid- $\beta$ protein aggregation and cerebrovascular amyloid- $\beta$ toxicity. Acta Neuropathol 111:139-149. CrossRef Medline

Yew EH, Cheung NS, Choy MS, Qi RZ, Lee AY, Peng ZF, Melendez AJ, Manikandan J, Koay ES, Chiu LL, Ng WL, Whiteman M, Kandiah J, Halliwell B (2005) Proteasome inhibition by lactacystin in primary neuronal cells induces both potentially neuroprotective and proapoptotic transcriptional responses: a microarray analysis. J Neurochem 94:943-956. CrossRef Medline

Zhang L, Blomgren K, Kuhn HG, Cooper-Kuhn CM (2009) Effects of postnatal thyroid hormone deficiency on neurogenesis in the juvenile and adult rat. Neurobiol Dis 34:366-374. CrossRef Medline 